\title{
Application of fuzzy logic and analytical hierarchy process (AHP) to landslide susceptibility mapping at Haraz watershed, Iran
}

\author{
Hamid Reza Pourghasemi • Biswajeet Pradhan • Candan Gokceoglu
}

Received: 15 January 2012/ Accepted: 12 April 2012/Published online: 26 May 2012

(C) Springer Science+Business Media B.V. 2012

\begin{abstract}
The main goal of this study is to produce landslide susceptibility maps of a landslide-prone area (Haraz) in Iran by using both fuzzy logic and analytical hierarchy process (AHP) models. At first, landslide locations were identified by aerial photographs and field surveys, and a total of 78 landslides were mapped from various sources. Then, the landslide inventory was randomly split into a training dataset $70 \%$ (55 landslides) for training the models and the remaining $30 \%$ (23 landslides) was used for validation purpose. Twelve data layers, as the landslide conditioning factors, are exploited to detect the most susceptible areas. These factors are slope degree, aspect, plan curvature, altitude, lithology, land use, distance from rivers, distance from roads, distance from faults, stream power index, slope length, and topographic wetness index. Subsequently, landslide susceptibility maps were produced using fuzzy logic and AHP models. For verification, receiver operating characteristics curve and area under the curve approaches were used. The verification results showed that the fuzzy logic model $(89.7 \%)$ performed better than AHP $(81.1 \%)$ model for the study area. The produced susceptibility maps can be used for general land use planning and hazard mitigation purpose.
\end{abstract}

Keywords Landslide - Susceptibility mapping · Fuzzy logic · AHP · GIS · Haraz • Remote sensing · Iran

H. R. Pourghasemi

Department of Watershed Management Engineering, College of Natural Resources and Marine

Sciences, Tarbiat Modares University (TMU), Tehran, Iran

B. Pradhan $(\square)$

Faculty of Engineering, Institute of Advanced Technology (ITMA), Spatial and Numerical Modeling Research Group, University Putra Malaysia (UPM), 43400 Serdang, Selangor Darul Ehsan, Malaysia e-mail: biswajeet24@gmail.com; biswajeet@lycos.com

C. Gokceoglu

Engineering Faculty, Applied Geology Division, Department of Geological Engineering, Hacettepe University, Ankara, Turkey 


\section{Introduction}

Over the last two decades, many governments and international research institutes in the world have invested considerable resources in assessing landslide hazard mapping by portraying their spatial distribution (Guzzetti et al. 1999). Landslides have caused large numbers of casualties and huge economic losses in mountainous areas of the world. It has been estimated that nearly 600 people are killed every year worldwide as a consequence of slope failure (Varnes 1981; Mowen et al. 2003). In many developing countries, natural catastrophes account for 1-2\% of the gross national product (Hutchinson 1995). According to the data of Iranian Landslide Working Party (2007), in Iran, about 187 people have been killed by landslides, and total economic losses from mass movements until the end of September 2007 have been estimated at 127,000 billion Iranian Rials (almost \$ 12,700 million dollars).

Landslide susceptibility mapping relies on a rather complex knowledge of slope movements and their controlling factors. The reliability of landslide susceptibility maps mainly depends on the amount and quality of available data, the working scale, and the selection of the appropriate methodology of analysis and modeling (Baeza and Corominas 2001).

Landslide inventory and susceptibility mapping studies are accepted as the first stage of landslide hazard mitigation efforts (Ercanoglu et al. 2004). These maps provide important information to support decisions for urban development and land use planning. Also, effective utilization of these maps can considerably reduce damage potential and other cost-effects of landslides. The process of creating landslide susceptibility maps involves several qualitative or quantitative approaches (Aleotti and Chowdhury 1999).

Landslide susceptibility maps are produced to help humans to recognize, avoid, or otherwise adapt to landslide hazard mitigation procedures. Guzzetti et al. (1999) conducted GIS-based studies in the Umbria and Marches regions of central Italy and also summarized many case studies of landslide hazard evaluation along the Apennines Mountains. Reports of landslide analyses using GIS and probabilistic models were also published (Van Westen et al. 1999; Clerici et al. 2006; Lee and Pradhan 2006; Pradhan et al. 2006, 2011; Akgun et al. 2008; Youssef et al. 2009, 2012; Akgun et al. 2011; Pradhan and Lee 2010a; Pradhan and Youssef 2010). Most of the above studies have been conducted using the regional landslide inventories derived from aerial photographs and remotely sensed images. Statistical models such as logistic regression also have been used in landslide susceptibility mapping (Wang and Sassa 2005; Lee and Sambath 2006; Lee and Pradhan 2007; Pradhan et al. 2008, 2010b, c; Tunusluoglu et al. 2008; Nefeslioğlu et al. 2008a; Pradhan 2010c). The application of the analytical hierarchy process (AHP) method, developed by Saaty (1977), has been used by many authors worldwide (Barredo et al. 2000; Nie et al. 2001; Yagi 2003; Ayalew et al. 2005; Komac 2006; Yoshimatsu and Abe 2006; Yalcin 2008; Ercanoglu et al. 2008; Akgun and Turk 2010). All these models provide solutions for integrating information levels and mapping the outputs. Recently, other new methods have been applied for landslide susceptibility evaluation using evidential belief function model (Park 2010; Althuwaynee et al. 2012); fuzzy logic (Ercanoglu and Gokceoglu 2002, 2004; Lee 2007; Pradhan and Lee 2009; Pradhan 2011a, b; Akgun et al. 2012) and artificial neural network models (Lee et al. 2004b; Pradhan and Lee 2007, 2009, 2010b; Biswajeet and Saied 2010; Pradhan et al. 2010a; Pradhan and Buchroithner 2010). More recently, new techniques have been used for landslide susceptibility mapping such as neuro-fuzzy (Kanungo et al. 2005; Lee et al. 2009; Pradhan et al. 2010d; Vahidnia et al. 2010; Sezer et al. 2011; Oh and Pradhan 2011), support vector machine (SVM) (Brenning 2005; Yao 
et al. 2008; Yilmaz 2010), and decision-tree methods (Nefeslioglu et al. 2010) have been tried and their performances have been assessed. The spatial results of these approaches are generally appealing, and they give rise to qualitatively and quantitatively map of the landslide hazard areas (Pradhan 2010a).

In this paper, we considered a fuzzy logic-based approach and analytical hierarchy process (AHP) to produce landslide susceptibility maps at the Haraz watershed in Iran (Fig. 1). These models exploit information obtained from an inventory map to predict where landslides may occur in future. These models are tested, and the results are
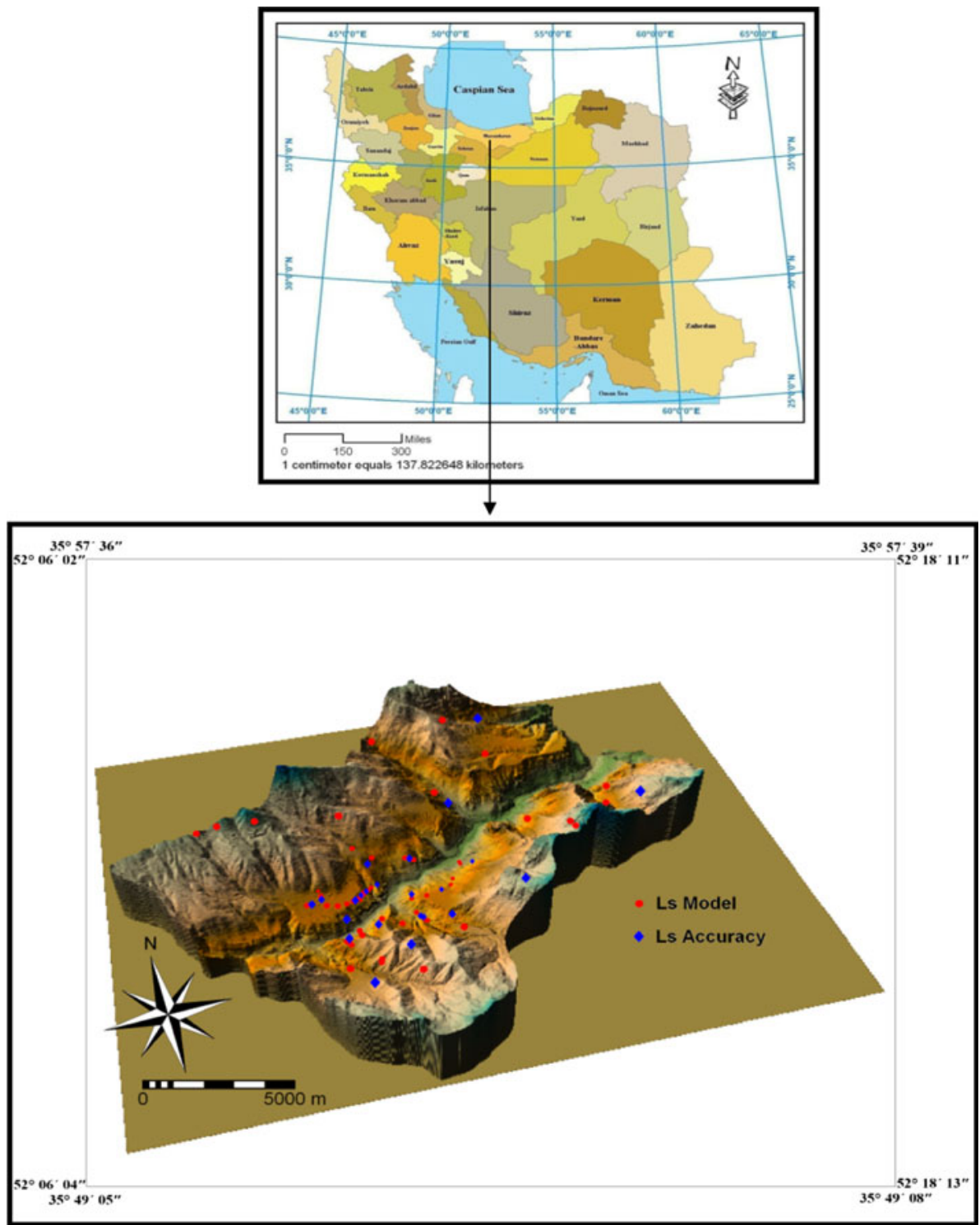

Fig. 1 Location of the Haraz watershed and landslide inventory map 
discussed. In the literature, fuzzy approach including data-driven membership functions for landslide susceptibility (Ercanoglu and Gokceoglu 2002) and Mamdani fuzzy inference system for landslide susceptibility (Akgun et al. 2012) exists. However, a comparison of fuzzy approaches with another expert-based system such as AHP is not encountered. This contribution provides originality to this study.

\section{Study area}

The study area is located at the north of Iran, one of the most landslide-prone areas in Iran (Pourghasemi 2008). The watershed area lies between the longitudes of $52^{\circ} 06^{\prime} 02^{\prime \prime} \mathrm{E}$ to $52^{\circ} 18^{\prime} 13^{\prime \prime} \mathrm{E}$ and latitudes of $35^{\circ} 49^{\prime} 05^{\prime \prime} \mathrm{N}$ to $35^{\circ} 57^{\prime} 39^{\prime \prime} \mathrm{N}$ is mountainous and lies in the geological Alborz Folded zone (Fig. 1). It covers two adjacent 1:50,000 topographic sheets of the Army Geographic Institute of Iran and has an extent of about $114.5 \mathrm{~km}^{2}$. Main stream in the study area is the Haraz River. The temperature varies between $-25{ }^{\circ} \mathrm{C}$ in winter and $36.5^{\circ} \mathrm{C}$ in summer. The mean annual rainfall is around $500 \mathrm{~mm}$. In general, the precipitation falls between November and January based on the records from the Iranian Meteorological Department. Altitude in the study area varies between 1,200 to 3,290 m. The majority of the area is covered by moderate pasture $(64.3 \%)$. The other parts of the study area are utilized for orchard and agricultural (13.4\%), residential $(0.3 \%)$, and good pasture $(21.9 \%)$.

\section{Production of the thematic data layers}

Various thematic data layers representing landslide conditioning factors namely slope degree, aspect, plan curvature, altitude, lithology, land use, distance from faults, distance from rivers, distance from roads, stream power index (SPI), slope length (LS), and topographic wetness index (TWI) were prepared. These factors fall under the category of preparatory factors, responsible for the occurrence of landslides in the region for which pertinent data can be collected from available resources as well as from the field. The triggering factors such as rainfall and earthquake set off the movement by shifting the slope from a marginally stable to an actively unstable area. The attributes of the ground in terms of landslide susceptibility are considered. Rainfall and earthquakes are triggering factors and temporal phenomena. However, past data on these triggering factors in relation to landslide occurrence are not available, and therefore, these factors are not considered in this study.

\subsection{Landslide inventory map}

The mapping of existing landslides is essential to study the relationship between the landslide distribution and the conditioning factors. In order to produce a detailed and reliable landslide inventory map, extensive field surveys and observations are performed in the study area. A total of 78 landslides are identified and mapped by evaluating aerial photos in 1:25,000 scale with well supported by field surveys (Fig. 1). The mode of failure of the landslides identified in the study area is rotational sliding according to the landslide classification proposed by Varnes (1978). Of the 78 landslides identified, randomly 55 ( $\cong 70 \%$ ) locations were chosen for the landslide susceptibility maps, while the remaining $23(\cong 30 \%)$ cases were used for the model validation. 


\subsection{Slope degree}

The main parameter of the slope stability analysis is the slope degree (Lee and Min 2001). Because the slope degree is directly related to the landslides, it is frequently used in preparing landslide susceptibility maps (Clerici et al. 2002; Ercanoglu et al. 2004; Lee et al. 2004a; Saha et al. 2005; Lee 2005). For this reason, the slope degree map of the study area is prepared from the digital elevation model (DEM) and divided into six slope categories (Fig. 2a). An integrated land and water information system (ILWIS 3.3) software was used to discover in which slope group the landslide occurred and the rate of occurrence is observed.

\subsection{Aspect}

Aspect is accepted as a main landslide conditioning factor, and this parameter is considered in several studies (van Westen and Bonilla 1990; Fernandez et al. 1999; Ercanoglu et al. 2004; Lee et al. 2004a). Some of the meteorological events such as the amount of rainfall, amount of sunshine, and the morphologic structure of the area affect the propensity of landslides. The hillsides receiving dense rainfall reach saturation faster; however, this is also related to filtering capacity of the slope controlled by various parameters such as slope topography, soil type, permeability, porosity, humidity, organic ingredients, land cover, and the climatic season. As a result, pore water pressure of the slope-forming material changes. In this study, the aspect map of the study area is produced to show the relationship between aspect and landslides (Fig. 2b). Aspects are grouped into 9 classes such as flat $(-1)^{\circ}$, north $\left(337.5^{\circ}-360^{\circ}, 0^{\circ}-22.5^{\circ}\right)$, northeast $\left(22.5^{\circ}-67.5^{\circ}\right)$, east $\left(67.5^{\circ}-112.5^{\circ}\right)$, southeast $\left(112.5^{\circ}-157.5^{\circ}\right)$, south $\left(157.5^{\circ}-202.5^{\circ}\right)$, southwest $\left(202.5^{\circ}-247.5^{\circ}\right)$, west $\left(247.5^{\circ}-292.5^{\circ}\right)$, and northwest $\left(292.5^{\circ}-337.5^{\circ}\right)$.

\subsection{Altitude}

Altitude is also a relevant landslide conditioning factor used in this study. The altitude map was prepared from the $10 \mathrm{~m} \times 10 \mathrm{~m}$ digital elevation model (Fig. 2c).

\subsection{Plan curvature}

The term curvature is theoretically defined as the rate of change of slope gradient or aspect, usually in a particular direction (Wilson and Gallant 2000). The curvature value can be evaluated by calculating the reciprocal value of the radius of curvature of that particular direction (Nefeslioğlu et al. 2008b). Hence, while the curvature values of broad curves are small, the tight ones have higher values. Plan curvature is described as the curvature of a contour line formed by intersecting a horizontal plane with the surface (Fig. 2d). The influence of plan curvature on the slope erosion processes is the convergence or divergence of water during downhill flow (Ercanoglu and Gokceoglu 2002; Oh and Pradhan 2011). For this reason, this parameter constitutes one of the conditioning factors controlling landslide occurrence (Nefeslioğlu et al. 2008b). The plan curvature map was produced using a system for automated geoscientific analyses (SAGA) GIS.

\subsection{Lithology}

The landslide phenomenon, a part of geomorphologic studies, is related to the lithology of the land. Since different lithological units have different landslide susceptibility values, 

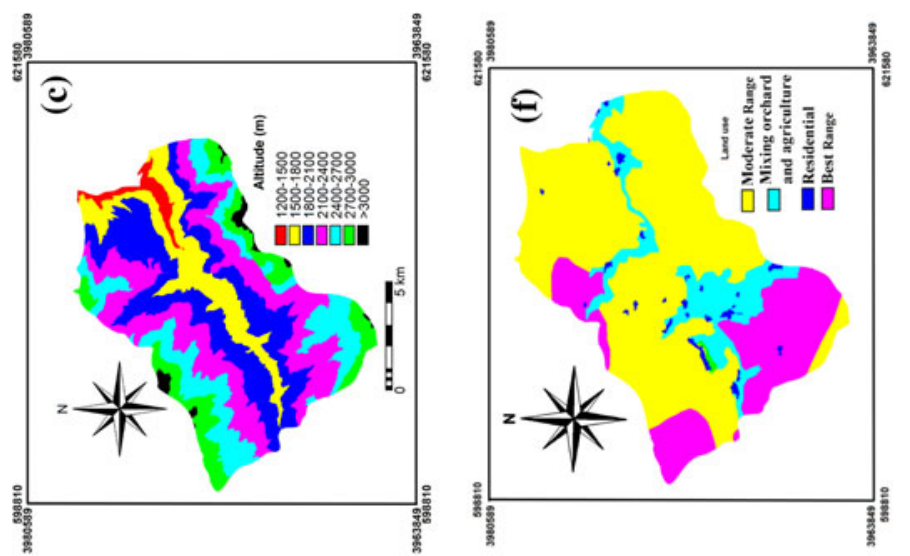

(3)
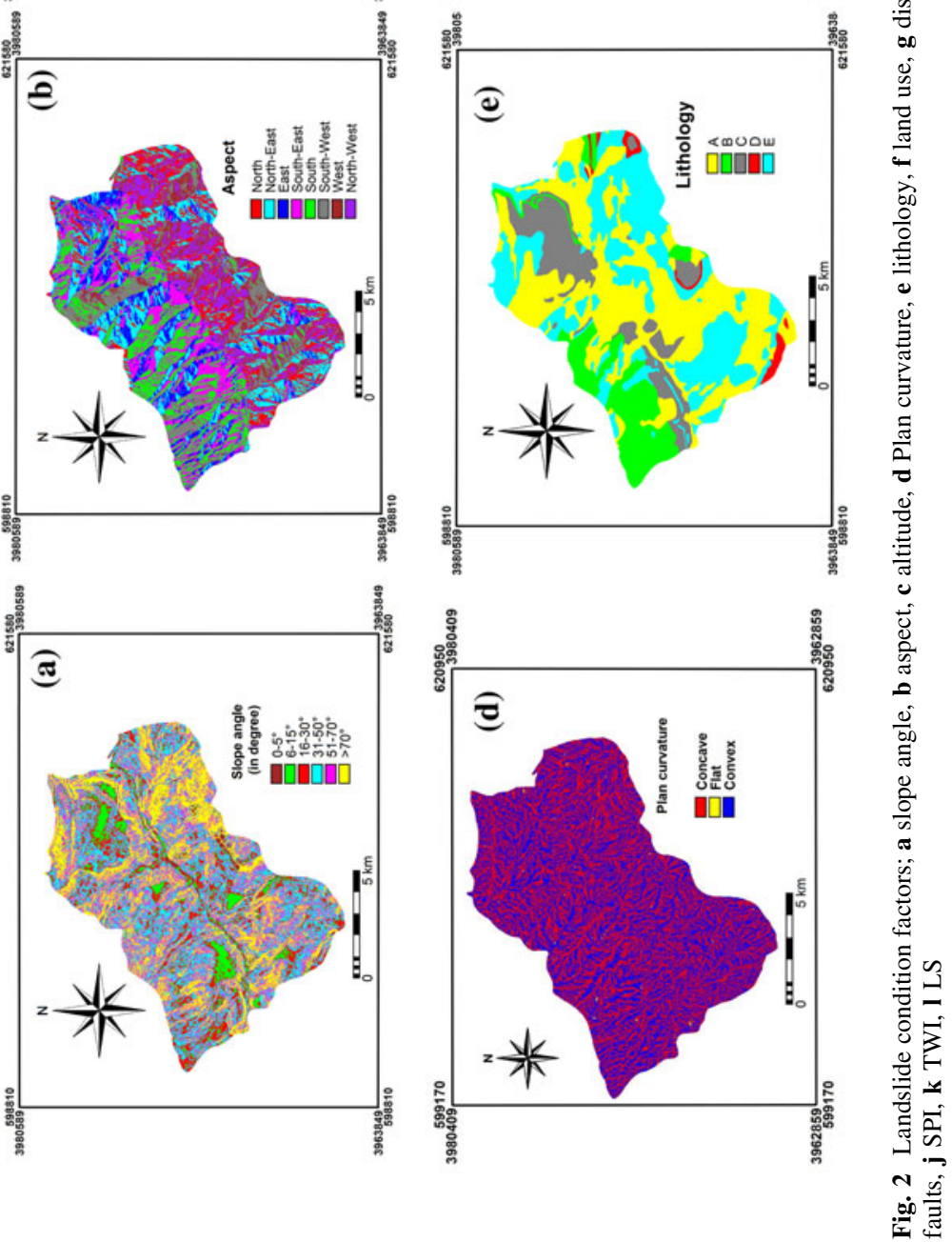

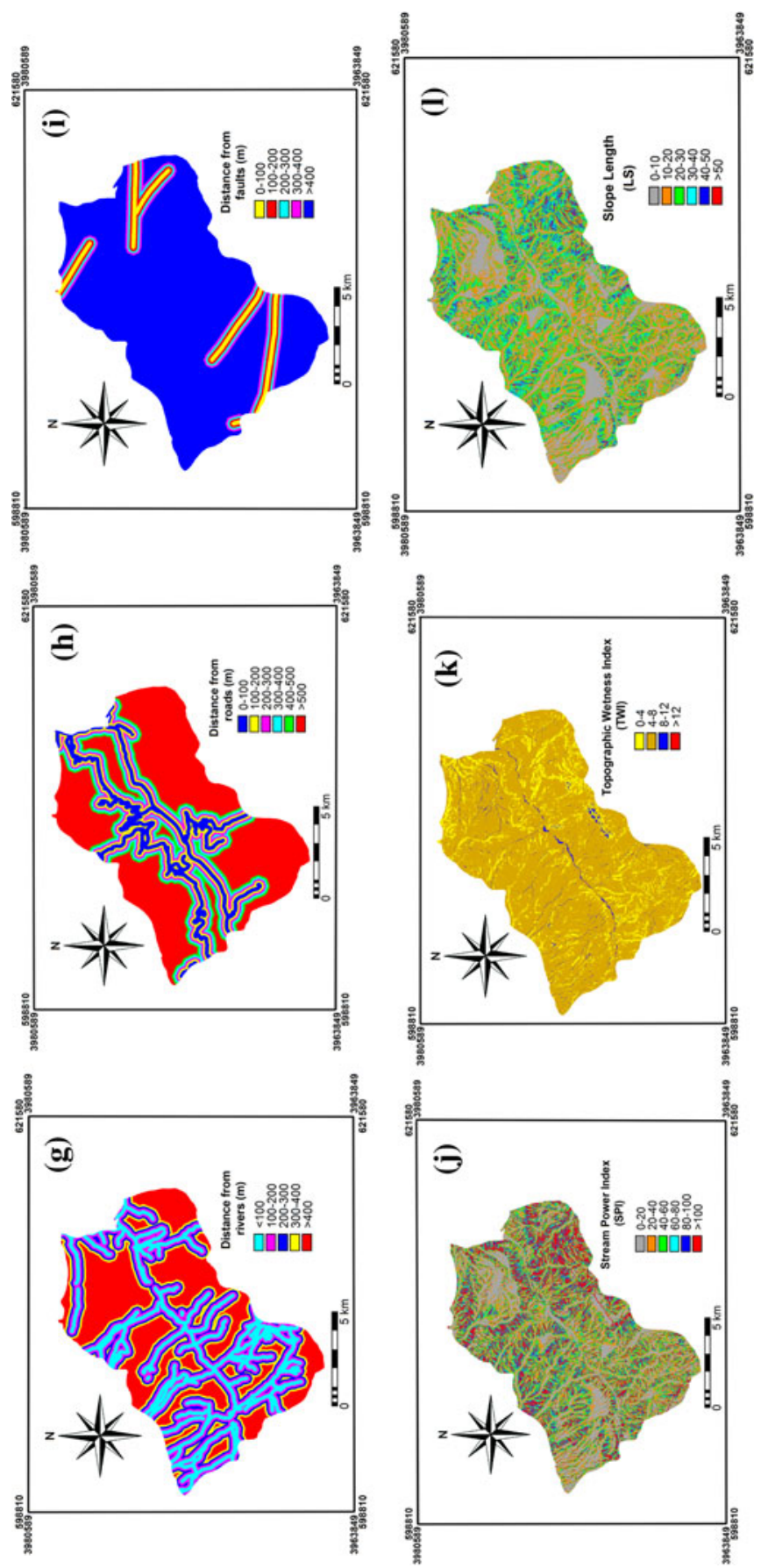

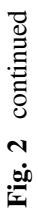


they are very important in providing data for susceptibility studies. For this reason, it is essential to group the lithological properties properly (Dai et al. 2001; Duman et al. 2006). Therefore, the geological map of the study area was prepared by the Geological Survey of Iran (GSI) at 1:100,000 scale (sheet number 6461) and was digitized in GIS. The study area is covered with various types of lithological units. The general geological setting of the area is shown in Fig. 2e, and the lithological properties are summarized in Table 1.

\subsection{Land use}

Four different types of land use were described for this study using a supervised classification (method: maximum likelihood, accuracy: $88 \%$ ) and field surveys of $\mathrm{ETM}^{+}(2006)$ satellite images. These types of land use were moderate pasture, best pasture, mixing orchard, and agricultural and residential areas (Fig. 2f). Most of the study area is covered by moderate pasture $(64.32 \%)$. It is well known that land use and vegetation cover play important roles in the stability of slopes (Ocakoglu et al. 2002).

\subsection{Distance from rivers}

An important parameter that controls the stability of a slope is the saturation degree of the material on the slope (Yalcin and Bulut 2007; Yalcin 2008). The closeness of the slope to drainage structures is another important factor in terms of stability. Streams may adversely affect stability by eroding the slopes or by saturating the lower part of material resulting in

Table 1 Description of geological units of the study area

\begin{tabular}{|c|c|c|c|c|}
\hline $\begin{array}{l}\text { Geological } \\
\text { age }\end{array}$ & Lithology & Formation & Symbol & No. \\
\hline Quaternary & Scree & - & $Q^{\mathrm{sc}}$ & A \\
\hline Quaternary & Young terraces & - & $Q_{2}^{\mathrm{t}}$ & \\
\hline Quaternary & Old terraces & - & $Q_{1}^{\mathrm{t}}$ & \\
\hline Quaternary & Agglomerate & - & $Q^{\mathrm{ag}}$ & \\
\hline Quaternary & Trachy andesitic lava flows & - & $Q^{\mathrm{ta}}$ & \\
\hline Quaternary & Ash tuff, lapilli tuff & - & $Q^{\mathrm{tu}}$ & \\
\hline Quaternary & Olivine basalt & - & $Q^{\mathrm{b}}$ & \\
\hline Eocene & $\begin{array}{l}\text { Green tuff, basaltic and limestone with gypsum, and } \\
\text { conglomerate }\end{array}$ & Karaj & $K_{\mathrm{k}}^{\mathrm{tv}}$ & B \\
\hline Eocene & Gypsum & Karaj & $E_{\mathrm{k}}^{\mathrm{gy}}$ & \\
\hline Paleocene & Limestone bearing nummulites and alveolina, conglomerate & Ziarat & $\mathrm{PE}_{\mathrm{z}}$ & $\mathrm{C}$ \\
\hline Paleocene & Conglomerate, agglomerate, some marl, and limestone & Fajan & $\mathrm{PE}_{\mathrm{f}}$ & \\
\hline $\begin{array}{l}\text { Late } \\
\text { Cretaceous }\end{array}$ & Biogenic and cherty limestone & - & $K_{2}$ & $\mathrm{D}$ \\
\hline $\begin{array}{l}\text { Late } \\
\text { Cretaceous }\end{array}$ & Orbitoline bearing limestone & Tizkuh & $K_{\mathrm{t}}$ & \\
\hline Late Jurassic & Massive to well-bedded, cherty limestone & Lar & $J_{1}$ & \\
\hline Late Jurassic & $\begin{array}{l}\text { Well-bedded, partly oolitic-detritic limestone, marly } \\
\text { limestone }\end{array}$ & Dalichai & $J_{\mathrm{d}}$ & \\
\hline Late Jurassic & Dark shale and sandstone with plant remains, coal & Shemshak & $J_{\mathrm{S}}$ & $\mathrm{E}$ \\
\hline Early Triassic & Thin-bedded limestone & Elika & $\mathrm{TR}_{\mathrm{eL}}$ & \\
\hline Early Permian & Cross-bedded, quartzitic sandstone & Dorud & $P_{\mathrm{d}}$ & \\
\hline
\end{tabular}


water level increases (Gokceoglu and Aksoy 1996; Saha et al. 2002). For this reason, five different buffer zones were created within the study area to determine the degree to which the streams affected the slopes (Fig. 2g). Euclidean distance method was applied, and a visual inspection was done to see the correlation between the river and landslide.

\subsection{Distance from roads}

Similar to the effect of the distance from rivers, landslides may occur on the road and on the side of slopes affected by roads (Pachauri et al. 1998; Ayalew and Yamagishi 2005).

Change of slope (over steepening) due to excavation, additional load, change in hydrology, and drainage may affect the stress state and slope equilibrium. In fact, during the field works, some landslides owing to road construction work are detected. For this reason, five different buffer zones are created on the path of the road to determine the effect of the road on the stability of slope (Fig. 2h). The landslide percentage distribution and its frequency ratio are determined considering the distance classes to the road by comparing the map of the distance to the road and the landslide inventory.

\subsection{Distance from faults}

The distance from faults is calculated at 100-m intervals using the geological map (Fig. 2i). Euclidean distance method was applied, and a visual inspection was done to see the correlation between the faults and landslides. Faults form a line or zone of weakness characterized by heavily fractured rocks (Foumelis et al. 2004). Generally speaking, farther the distance from tectonic structures will result less numbers of landslides. Selective erosion and movement of water along fault planes promote such phenomena. Apart from the major thrusts and faults derived from the geological maps, some complementary information regarding possible faults and structural dislocations was recognized as lineaments by means of image enhancement (filtering) of satellite imagery. The recognition of lineaments were performed step-by-step from large to smaller scales allowing the generalization of many neighboring small-order lineaments taking into account the spatial scale of the study (Fig. 2i).

\subsection{Stream power index (SPI)}

The stream power index (SPI) is a compound topographic attribute. It is a measure of the erosive power of flowing water based on the assumption that discharge is proportional to specific catchment area (Fig. $2 \mathrm{j}$ ). It generally predicts net erosion in the areas of profile and tangential convexity (flow acceleration and convergence zones) and net deposition in the areas of profile concavity (zones of decreasing flow velocity). Stream power index was calculated based on the formula given by Moore et al. (1991).

$$
\mathrm{SPI}=A_{\mathrm{S}} \times \tan \beta
$$

where $A_{\mathrm{S}}$ is the specific catchment's area and $\beta$ is the local slope gradient measured in degrees.

\subsection{Topographic wetness index (TWI)}

Another topographic factor within the runoff model is the topographic wetness index (TWI). A topographic wetness index measures the degree of accumulation of water at a site (Fig. 2k). It is defined as (Beven and Kirkby 1979; Moore et al. 1991): 


$$
\mathrm{TWI}=\ln (a / \tan \beta)
$$

where $a$ is the cumulative upslope area draining through a point (per unit contour length) and $\tan \beta$ is the slope angle at the point. The $\ln (a / \tan \beta)$ index reflects the tendency of water to accumulate at any point in the catchment (in terms of a) and the tendency of gravitational forces to move that water down slope (expressed in terms of $\tan \beta$ as an approximate hydraulic gradient). The water infiltration primarily depends upon material properties such as permeability, pore water pressure, and effects on the soil strength (Pouydal et al. 2010).

\subsection{Slope length (LS)}

Besides the stream power index and topographic wetness index, there is also another factor included, that is, slope length (LS). The soil loss is a combined effect of length (L) and slope steepness (S). The LS factor in the Universal Soil Loss Equation (USLE) is a measure of the sediment transport capacity of overland flow (Moore and Wilson 1992). Slope length is the distance from the origin of overland flow along its flow path to the location of either concentrated flow or deposition. The larger the slope length, the more water accumulates at the bottom of the field, increasing erosion. It also depends on the surface slope. Carrara et al. (1995) stated that there is a relationship between slide density and slope length. The slope length factor was calculated based on work by Moore and Burch (1986) using Eq. (3).

$$
\mathrm{LS}=\left(\frac{A_{\mathrm{S}}}{22.13}\right)^{0.6}\left(\frac{\sin \beta}{0.0896}\right)^{1.3}
$$

These indices can be estimated as a function of primary terrain attributes and can be easily implemented in SAGA GIS (Fig. 21).

\section{Landslide susceptibility mapping}

\subsection{Application of fuzzy logic model}

The fuzzy set theory introduced by Zadeh (1965) is one of the tools used to handle a complex problems. Therefore, the fuzzy set theory has been commonly used for many scientific studies in different disciplines. The idea of fuzzy logic is to consider the spatial objects on a map as the members of a set. In the classical set theory, an object is a member of a set if it has a membership value of 1 or is not a member if it has a membership value of 0 (Hines 1997). In the fuzzy set theory, membership can take on any value between 0 and 1, reflecting the degree of certainty of membership (Zadeh 1965). The fuzzy set theory employs the idea of a membership function that expresses the degree of membership with respect to some attribute of interest. With maps, generally, the attribute of interest is measured over discrete intervals, and the membership function can be expressed as a table, relating map classes to membership values (Pradhan 2010b, 2011a, b). Fuzzy logic is attractive because it is straightforward to understand and implement. It can be used with data from any measurement scale, and the weighting of evidence is controlled entirely by the expert. The fuzzy logic method allows more flexible combinations of weighted maps and could be readily implemented with a GIS modeling language (Pradhan 2010b). This is different from data-driven approaches such as weights of evidence or logistic regression, 
which use the locations of known objects such as landslides to estimate weights or coefficients (Pradhan 2011a, b) (Table 2).

The idea of using fuzzy approach in landslide susceptibility mapping is to consider the pixels on any causal factor layer as susceptible to landslides. Pixel values can be numeric and range from 0 (i.e., not susceptible) to 1 (i.e., "susceptible"). Pixel values must lie in the range of 0 to 1 , but there is no practical constraint on the choice of values. Values are chosen to reflect the degree of membership of a set, based on subjective judgment as shown by Bonham-Carter (1994) for mineral exploration, or they can be derived by various functions representing the reality such as J-shape, sigmoidal, and linear functions (Eastman 2003). These values can be user-defined, or can be derived from a frequency ratio (Lee 2007; Pradhan et al. 2009), or through analytical hierarchy process (Saaty 1977). In the present case, fuzzy membership values have been assigned based on frequency ratio model (Table 2). The frequency ratio, a ratio between the occurrence and non-occurrence of landslides in each pixel, is calculated for each factor's type or range that has been identified as significant with respect to causing landslides. An area ratio for each factor's type or range to the total area is determined. Finally, frequency ratios for each factor's type or range are calculated by dividing the landslide occurrence ratio by the area ratio as:

$$
\mathrm{Fr}=\frac{\text { landslide occurrence ratio }}{\text { area ratio }}
$$

Then, the frequency ratio is normalized between 0 and 1 to describe the fuzzy membership functions. For inference in a rule-based fuzzy model, the fuzzy propositions need to be represented by an implication function. The implication function is called a fuzzy if-then rule or a fuzzy conditional statement (Alvarez Grima 2000). A fuzzy set is a collection of paired members, which consist of members and degrees of "support" or "confidence" for those members. In a discrete form, the fuzzy set 'about 7 ' might be expressed as $(0.1 / 5$, $0.7 / 6,1 / 7,0.7 / 8,0.1 / 9)$. In a fuzzy set notation, the members after the slash $(/)$ are the members of the set (or appropriate numerical grades in each case), and the values before the slash are the degrees of confidence or "membership" of those numbers. The use of fuzzy sets to represent linguistic terms enables one to represent more accurately and consistently something which is fuzzy (Juang et al. 1992). A linguistic variable whose values are words, phrases, or sentences are labels of fuzzy sets (Zadeh 1973). In the present study, the following fuzzy sets are used to express the input parameters in linguistic forms:

1. Very low $=(1 / 1,0.75 / 2,0.5 / 3,0.25 / 4,0 / 5)$

2. Low $=(0 / 1,0.25 / 2,0.75 / 3,1 / 4,0 / 5)$

3. Moderate $=(0 / 1,0.5 / 2,1 / 3,0.5 / 4,0 / 5)$

4. High $=(0 / 1,1 / 2,0.75 / 3,0.25 / 4,0 / 5)$

5. Very high $=(0 / 1,0.25 / 2,0.5 / 3,0.75 / 4,1 / 5)$.

In addition to input sets, the outputs of each parameter are also classified into groups in terms of landslide susceptibility. The degrees of memberships in the fuzzy set representations for the outputs are obtained from the normalized results of frequency ratios. The fuzzy set representations of the conditioning parameters of the landslides are obtained as follows:

1. $\mu_{\mathrm{s}}$ Slope degree $=(0 / 1,0.34 / 2,1 / 3,0.84 / 4,0.38 / 5,0.37 / 6)$.

2. $\mu_{\mathrm{s}}$ Aspect $=(1 / 1,0.17 / 2,0.13 / 3,0.34 / 4,0.22 / 5,0.36 / 6,0.38 / 7)$.

3. $\mu_{\mathrm{s}}$ Altitude $=(0 / 1,1 / 2,0.56 / 3,0.19 / 4,0.24 / 5,0.07 / 6,0 / 7)$.

4. $\mu_{\mathrm{s}}$ Plan curvature $=(0 / 1,1 / 2)$. 


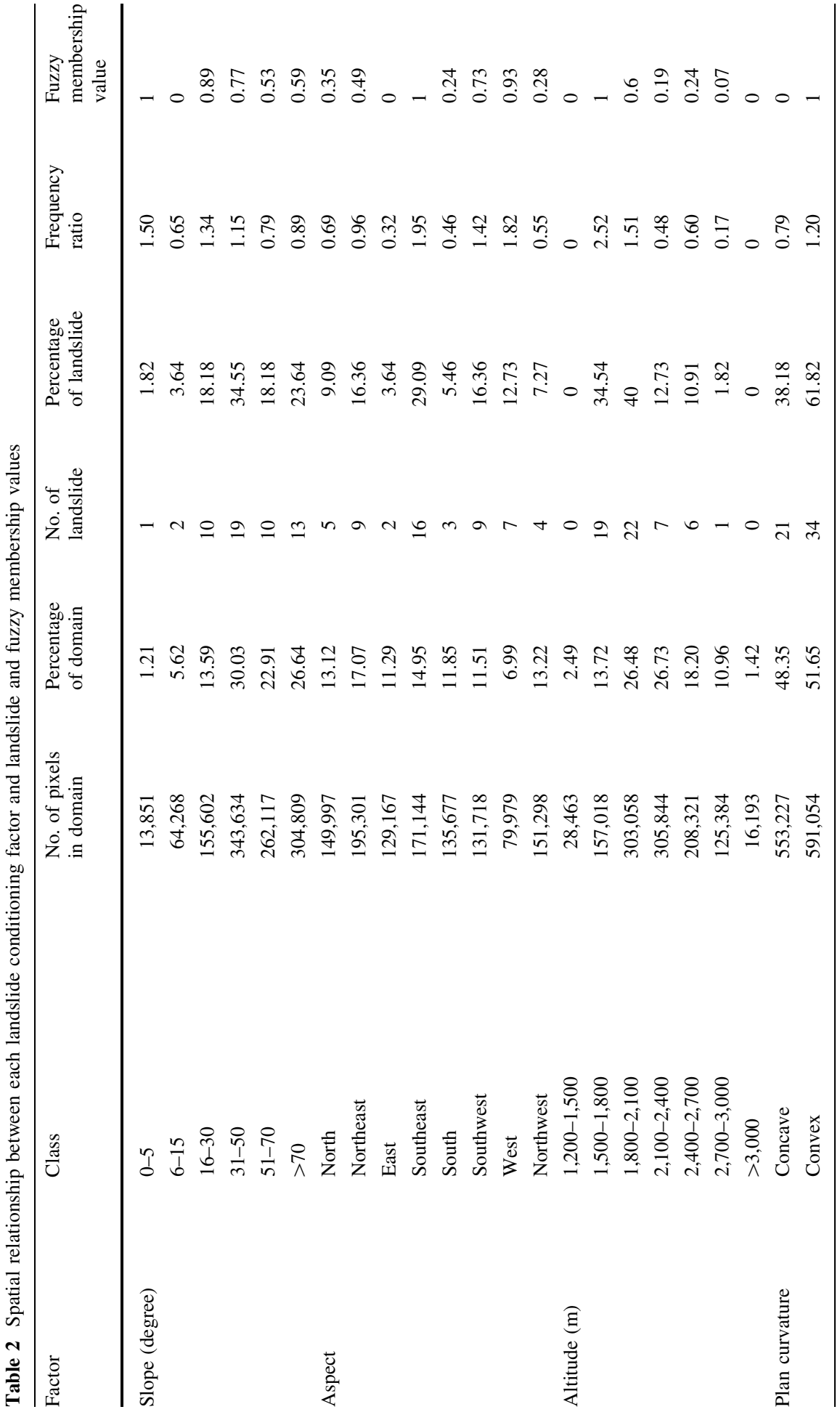




\begin{tabular}{|c|c|}
\hline 鹿蛋气 & 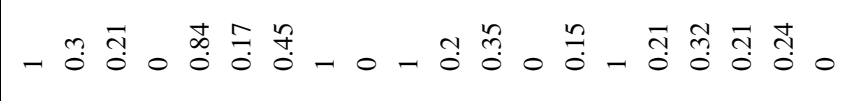 \\
\hline 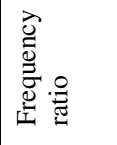 & 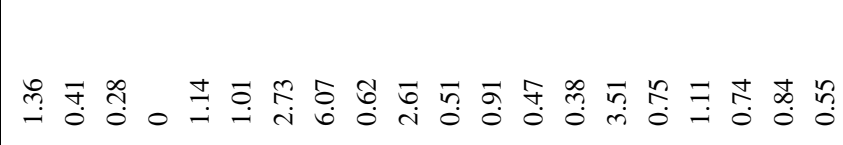 \\
\hline 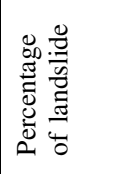 & 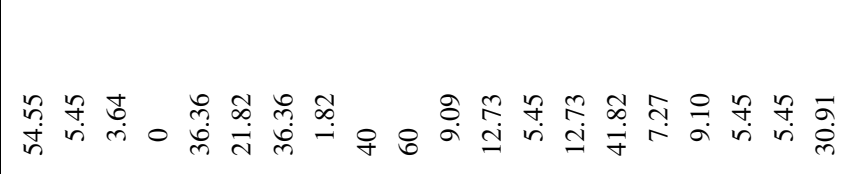 \\
\hline 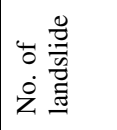 & mmno \\
\hline 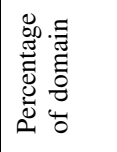 & 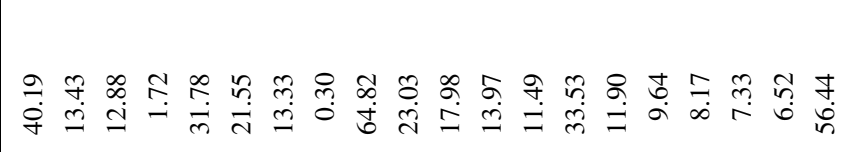 \\
\hline 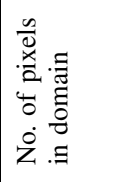 & 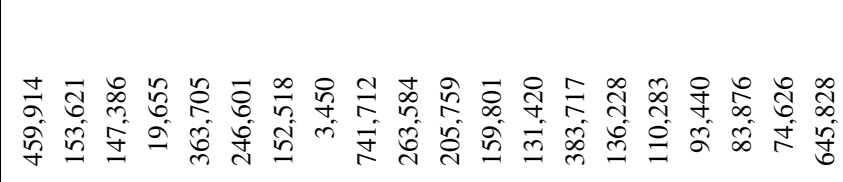 \\
\hline$\frac{\mathscr{\sigma}}{\tilde{J}}$ & 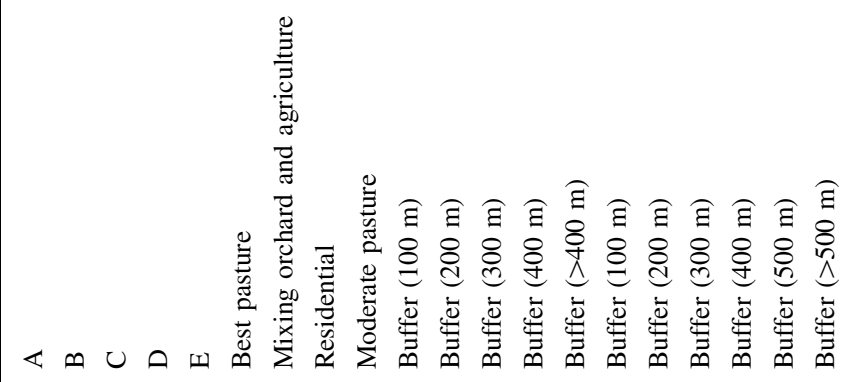 \\
\hline 产 & 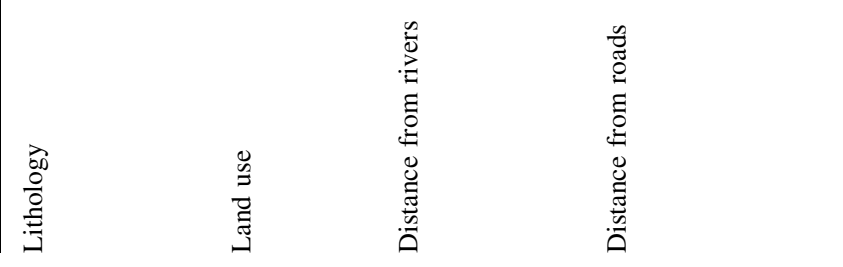 \\
\hline
\end{tabular}




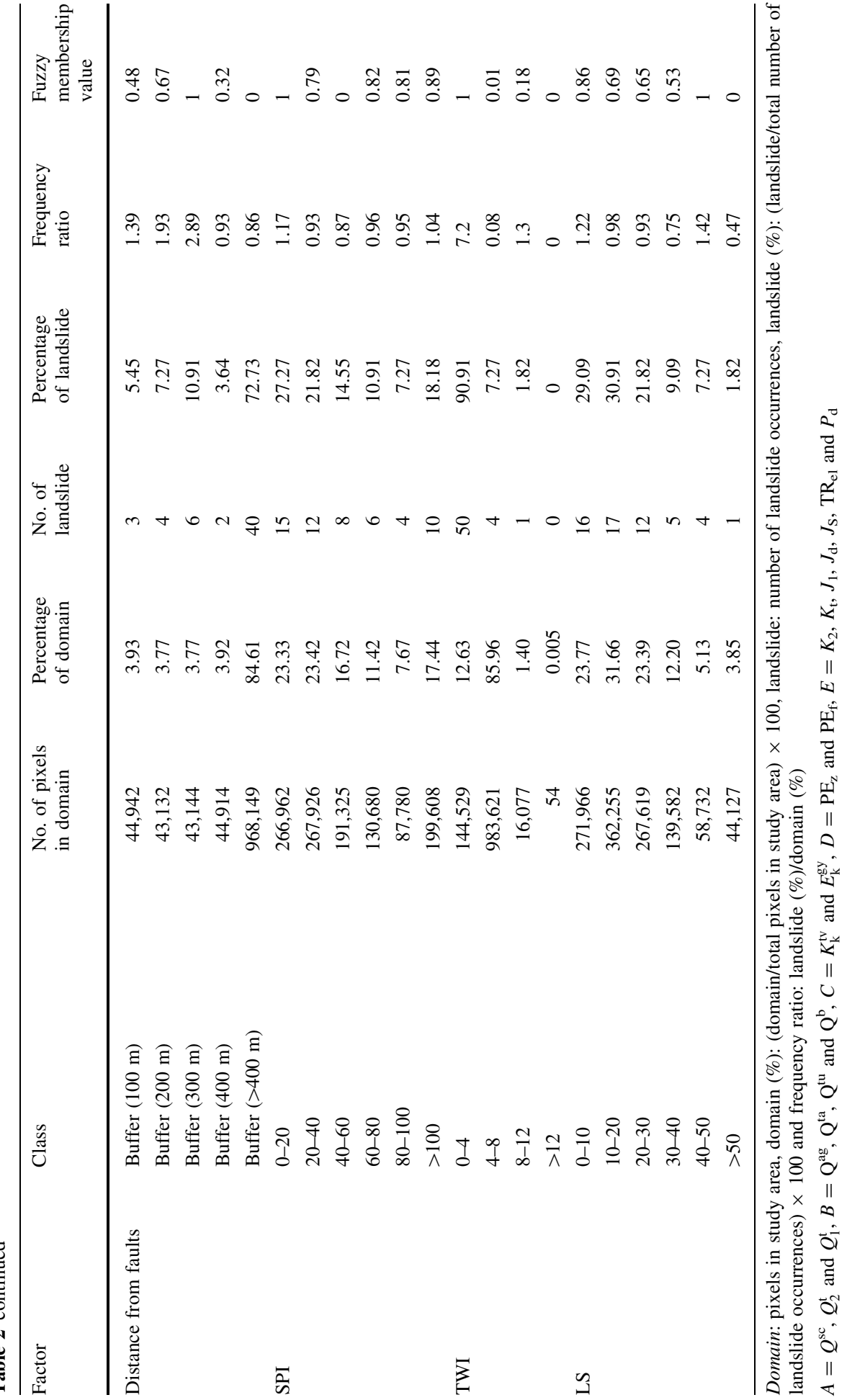


5. $\mu_{\mathrm{s}}$ Lithology $=(1 / 1,0.3 / 2,0.21 / 3,0 / 4,0.84 / 5)$.

6. $\quad \mu_{\mathrm{s}}$ Land use $=(0.03 / 1,0.07 / 2,1 / 3,0 / 4)$.

7. $\mu_{\mathrm{s}}$ Distance from faults $=(0.77 / 1,0.80 / 2,1 / 3,0.39 / 4,0 / 5)$.

8. $\mu_{\mathrm{s}}$ Distance from rivers $=(1 / 1,0.20 / 2,0.41 / 3,0 / 4,0.15 / 5)$.

9. $\mu_{\mathrm{s}}$ Distance from roads $=(1 / 1,0.16 / 2,0.24 / 3,0.27 / 4,0.22 / 5,0 / 6)$.

10. $\mu_{\mathrm{s}}$ TWI $=(1 / 1,0.01 / 2,0.18 / 3,0 / 4)$.

11. $\mu_{\mathrm{s}} \mathrm{SPI}=(1 / 1,0.79 / 2,0 / 3,0.74 / 4,0.81 / 5,0.89 / 5)$.

12. $\mu_{\mathrm{s}} \mathrm{LS}=(0.86 / 1,0.69 / 2,0.65 / 3,0.53 / 4,1 / 5,0 / 5)$.

In the next stage, the fuzzy sets representing the inputs and outputs as expressed above were extracted using the fuzzy rules (Table 3). Considering the fuzzy if-then rules expressed above, the fuzzified index maps representing slope degree, aspect, altitude, plan curvature, lithology, land use, distance from rivers, distance from roads, distance from faults, SPI, TWI, and LS are produced using the previously produced maps (Fig. 2a-m). When producing the fuzzified index maps, a grid-based (discrete) analysis is performed in GIS. Finally, all the fuzzified index maps were combined by overlying based on the maximum operator in fuzzy mathematics (Eq. 5).

$$
\mu_{\text {combination }}=\operatorname{MAX}\left(\mu_{\mathrm{A}}, \mu_{\mathrm{B}}, \mu_{\mathrm{C}}, \ldots\right) \text {. }
$$

Maximum values were calculated for each parameter combination and were assigned to represent the landslide susceptibility (Fig. 3). The main reason for taking the maximum value at each pixel is to evaluate the most effective parameter representing the landslide susceptibility (Ercanoglu and Gokceoglu 2004). Then, landslide susceptibility map was classified into 4 classes (low, moderate, high, and very high) based on natural break classification scheme (Falaschi et al. 2009; Bednarik et al. 2010; Constantin et al. 2010; Erner et al. 2010; Ram Mohan et al. 2011; Xu et al. 2012).

The frequency ratio depicts the spatial relationship between the landslide and landslide conditioning factors (Table 2). For slopes between 16 and 50, the ratio was $>1$, which indicates a high probability of landslide occurrence (Table 2). For slope angles 6-15, the frequency ratio was 0.65 , which indicates a very low probability of landslide occurrence (Table 2). However, for the slope $<5$, the frequency ratio value was 1.51 . This is because only one landslide has occurred in a relatively low number of pixel domains.

In the case of the slope aspect (Table 2), landslides were most abundant on southeast and west-facing slopes. The frequency of landslides was lowest on east-facing, southfacing, and north-facing slopes. In the case of altitude (Table 2), the frequency ratios $>1$ at intervals 1,500-1,800 m and 1,800-2,100 m (2.52 and 1.51, respectively). Results showed that the ratio decrease with the increase in altitude. In the case of lithology (Table 2), the frequency ratio was higher (1.36) in quaternary deposits (class A) and lower (0.00) in Paleocene age (class D). In the case of land use (Table 2), the landslide occurrence values were higher in residential areas (6.07) and lower in middle pasture areas (0.62).

In the case of distance from fault (Table 2), for distances 300-400 $\mathrm{m}$ and $>400 \mathrm{~m}$, the ratio is 0.93 and 0.86 , respectively, indicating a low probability of landslide occurrence. Subsequently, at distances of 0-100 m, 100-200, and 200-300 m, the frequency ratios are $1.39,1.93$, and 2.89 , respectively, indicating a high probability. This means that the landslide probability decreases with increasing distance from fault lines. For the distance from river (Table 2), it can be seen that the frequency ratio $>1$ at distance from river of $0-100 \mathrm{~m}$, whereas the values of frequency ratios $<1$ are at distances from river of 100-200 m, 200-300 m, 300-400 m, and >400 m. From this observation, we can say that 
Table 3 If-then rules used in the study area

\begin{tabular}{|c|c|c|}
\hline $\begin{array}{l}\text { Rule } \\
\text { no. }\end{array}$ & Antecedent part & Consequent part \\
\hline 1 & If slope is very low & Then landslide susceptibility is low \\
\hline 2 & If slope is moderate & Then landslide susceptibility is very high \\
\hline 3 & If slope is high or very high & Then landslide susceptibility is moderate \\
\hline 4 & If aspect is very low & Then landslide susceptibility is very high \\
\hline 5 & If aspect is low and high & Then landslide susceptibility is very low \\
\hline 6 & If aspect is moderate or very high & Then landslide susceptibility is low \\
\hline 7 & If altitude is very low & $\begin{array}{l}\text { Then landslide susceptibility is non- } \\
\text { susceptible }\end{array}$ \\
\hline 8 & If altitude is low & Then landslide susceptibility is very high \\
\hline 9 & If altitude is moderate & Then landslide susceptibility is moderate \\
\hline 10 & If altitude is high or very high & Then landslide susceptibility is very low \\
\hline 11 & If plan curvature is concave & Then landslide susceptibility is low \\
\hline 12 & If plan curvature is convex & Then landslide susceptibility is very high \\
\hline 13 & If lithology is (A) or (E) & Then landslide susceptibility is very high \\
\hline 14 & If lithology is $(B)$ or $(C)$ & Then landslide susceptibility is low \\
\hline 15 & If lithology is (D & $\begin{array}{l}\text { Then landslide susceptibility is non- } \\
\text { susceptible }\end{array}$ \\
\hline 16 & If land use is good pasture or orchard agriculture & Then landslide susceptibility is very low \\
\hline 17 & If land use is residential & Then landslide susceptibility is very high \\
\hline 18 & If land use is moderate pasture & $\begin{array}{l}\text { Then landslide susceptibility is non- } \\
\text { susceptible }\end{array}$ \\
\hline 19 & If distance from fault is very small or small & Then landslide susceptibility is high \\
\hline 20 & If distance from fault is moderate & Then landslide susceptibility is very high \\
\hline 21 & If distance from fault is high & Then landslide susceptibility is low \\
\hline 22 & If distance from fault is very high & $\begin{array}{l}\text { Then landslide susceptibility is non- } \\
\text { susceptible }\end{array}$ \\
\hline 23 & If distance from river is very small & Then landslide susceptibility is very high \\
\hline 24 & If distance from river is small & Then landslide susceptibility is low \\
\hline 25 & If distance from river is moderate & Then landslide susceptibility is moderate \\
\hline 26 & If distance from river is high & $\begin{array}{l}\text { Then landslide susceptibility is non- } \\
\text { susceptible }\end{array}$ \\
\hline 27 & If distance from river is very high & Then landslide susceptibility is very low \\
\hline 28 & If distance from road is very small & Then landslide susceptibility is very high \\
\hline 29 & If distance from road is low, moderate, or high & Then landslide susceptibility is low \\
\hline 30 & If distance from road is very high & $\begin{array}{l}\text { Then landslide susceptibility is non- } \\
\text { susceptible }\end{array}$ \\
\hline 31 & If SPI is very small or small & Then landslide susceptibility is very high \\
\hline 32 & If SPI is moderate & Then landslide susceptibility is moderate \\
\hline 33 & If SPI is high and very high & Then landslide susceptibility is low \\
\hline 34 & If TWI is small & Then landslide susceptibility is very high \\
\hline 35 & If TWI is moderate & Then landslide susceptibility is very low \\
\hline 36 & If TWI is high and very high & $\begin{array}{l}\text { Then landslide susceptibility is non- } \\
\text { susceptible }\end{array}$ \\
\hline 37 & If $\mathrm{LS}$ is very low & Then landslide susceptibility is high \\
\hline
\end{tabular}


Table 3 continued

\begin{tabular}{lll}
\hline $\begin{array}{l}\text { Rule } \\
\text { no. }\end{array}$ & Antecedent part & Consequent part \\
\hline 38 & If LS is low or moderate & Then landslide susceptibility is moderate \\
38 & If LS is high & Then landslide susceptibility is very high \\
40 & If LS is very high & $\begin{array}{c}\text { Then landslide susceptibility is non- } \\
\text { susceptible }\end{array}$ \\
\hline
\end{tabular}

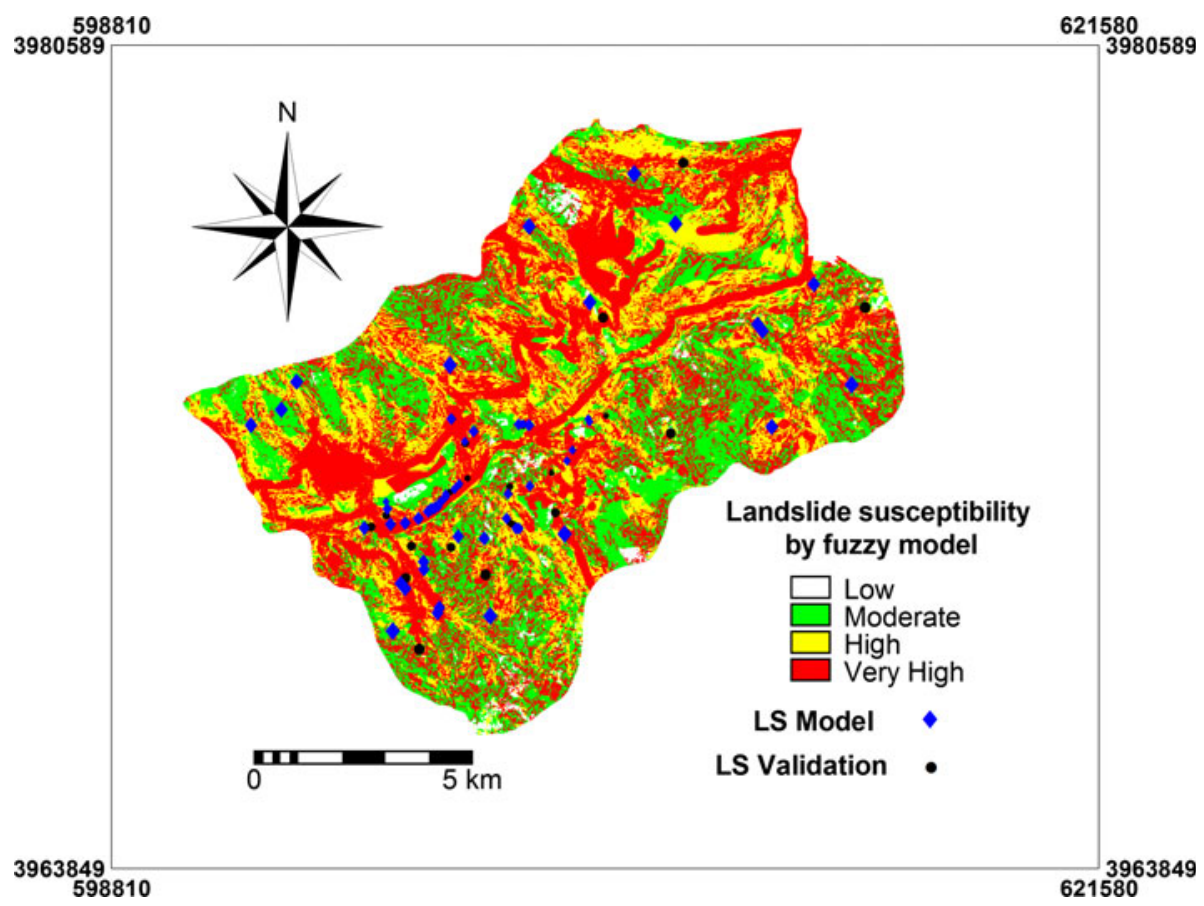

Fig. 3 Landslide susceptibility map based on fuzzy logic model

the general trend of the ratio decreases with the distance from the river. This can be attributed to the fact that terrain modification is caused by gully erosion, which may influence the initiation of landslides. For the distance from road, frequency ratio are 3.51 and 1.11 at distance of $0-100 \mathrm{~m}$ and $200-300 \mathrm{~m}$, respectively, whereas the values of frequency ratios $<1$ at distances of $100-200 \mathrm{~m}, 300-400 \mathrm{~m}, 400-500 \mathrm{~m}$, and $>500 \mathrm{~m}$. From this observation, we can say that the general trend of the ratio decreases with the distance from the road. In the case of CTI, frequency ratio is higher for the class 0-4 and $8-12$. In the case of SPI and LS, frequency ratios are higher (i.e., $>1$ ) for the range $0-20$ and 40-50, respectively.

\subsection{Application of analytical hierarchy process (AHP)}

The analytical hierarchy process (AHP) is a semi-qualitative method, which involves a matrix-based pair-wise comparison of the contribution of different factors for landsliding. 
AHP is a multi-objective, multi-criteria decision-making approach, which enables the user to arrive at a scale of preference drawn from a set of alternatives (Saaty 1980). It helps decision makers find out the best suits their goal and their understanding of the problem. This mathematical method widely used in site selection, suitability analysis, regional planning, routing modeling, and landslide susceptibility analysis. The process includes several steps: (1) break a complex unstructured problem down into its component factors which are the parameters chosen in this study; (2) arrange these factors in a hierarchic order; (3) assign numerical values according to their subjective relevance to determine the relative importance of each factor; and (4) synthesize the rating to determine the priorities to be assigned to these factors (Saaty and Vargas 2001). When arranging the factors in a hierarchic order, there should be relative importance of one factor over another forming a pair-wise comparison matrix with scores given in Table 4 . In the construction of a pairwise comparison matrix, each factor is rated against every other factor by assigning a relative dominant value between 1 and 9 to the intersecting cell (Table 5).

When the factor on the vertical axis is more important than the factor on the horizontal axis, this value varies between 1 and 9. Conversely, the value varies between the reciprocals $1 / 2$ and $1 / 9$. In these techniques, firstly, the effects of each parameter to the susceptibility of landslides relative to each other were determined by dual evaluation in determining the preferences in the effects of the parameters to the landslide susceptibility map. Normally, the determination of the values of the parameters relative to each other is a situation that depends on the choices of the decision maker. The landslide susceptibility map using AHP model was constructed using the following equation:

$$
\begin{aligned}
\mathrm{LSM}_{\mathrm{AHP}}= & \left(\left(\text { slope degree } \times W_{\mathrm{AHP}}\right)+\left(\text { aspect } \times W_{\mathrm{AHP}}\right)+\left(\text { altitude } \times W_{\mathrm{AHP}}\right)\right. \\
& \left.+\left(\text { plan curvature } \times W_{\mathrm{AHP}}\right)+\left(\text { lithology } \times W_{\mathrm{AHP}}\right)+\text { land use } \times W_{\mathrm{AHP}}\right) \\
& +\left(\text { distance from rivers } \times W_{\mathrm{AHP}}\right)+\left(\text { distance from roads } \times W_{\mathrm{AHP}}\right) \\
& +\left(\text { distance from faults } \times W_{\mathrm{AHP}}\right)+\left(\mathrm{SPI} \times W_{\mathrm{AHP}}\right)+\left(\mathrm{TWI} \times W_{\mathrm{AHP}}\right) \\
& \left.+\left(\mathrm{LS} \times W_{\mathrm{AHP}}\right)\right)
\end{aligned}
$$

\begin{tabular}{|c|c|c|}
\hline Scales & $\begin{array}{l}\text { Degree of } \\
\text { preference }\end{array}$ & Explanation \\
\hline 1 & Equally & Two activities contribute equally to the objective \\
\hline 3 & Moderately & $\begin{array}{l}\text { Experience and judgment slightly to moderately favor one } \\
\text { activity over another }\end{array}$ \\
\hline 5 & Strongly & $\begin{array}{l}\text { Experience and judgment strongly or essentially favor one } \\
\text { activity over another }\end{array}$ \\
\hline 7 & Very strongly & $\begin{array}{l}\text { An activity is strongly favored over another and its } \\
\text { dominance is showed in practice }\end{array}$ \\
\hline 9 & Extremely & $\begin{array}{l}\text { The evidence of favoring one activity over another is of the } \\
\text { highest degree possible of an affirmation }\end{array}$ \\
\hline $2,4,6,8$ & Intermediate values & $\begin{array}{l}\text { Used to represent compromises between the preferences in } \\
\text { weights } 1,3,5,7 \text {, and } 9\end{array}$ \\
\hline Reciprocals & Opposites & Used for inverse comparison \\
\hline
\end{tabular}

where $W_{\mathrm{AHP}}$ is the weightage for the each landslide conditioning factor. The pixel values obtained are then classified into 4 classes (low, moderate, high, and very high) based on natural break to determine the class intervals in the landslide susceptibility map (Fig. 4).

Table 4 Scale of preference between two parameters in AHP (Saaty 2000) 


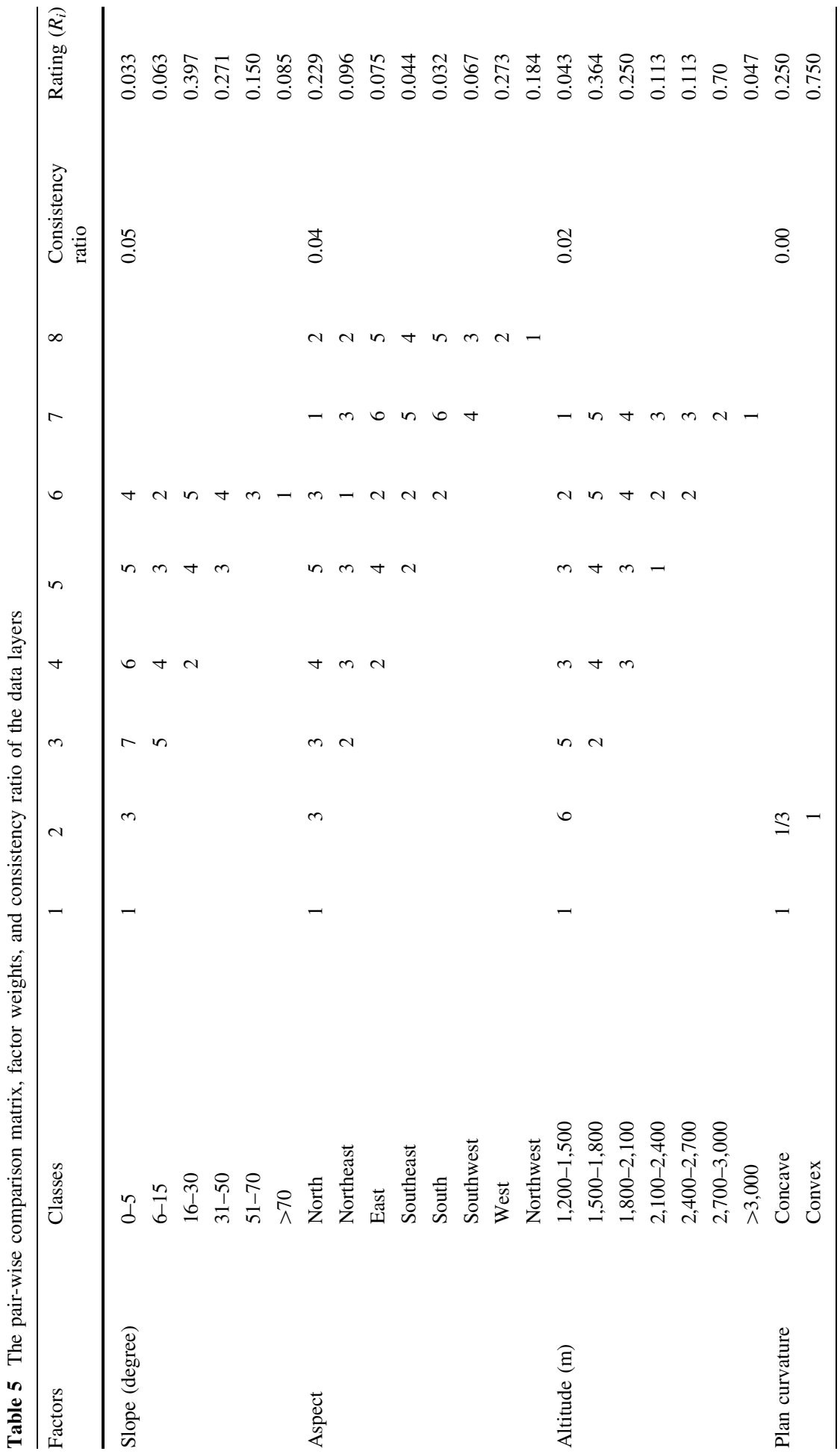




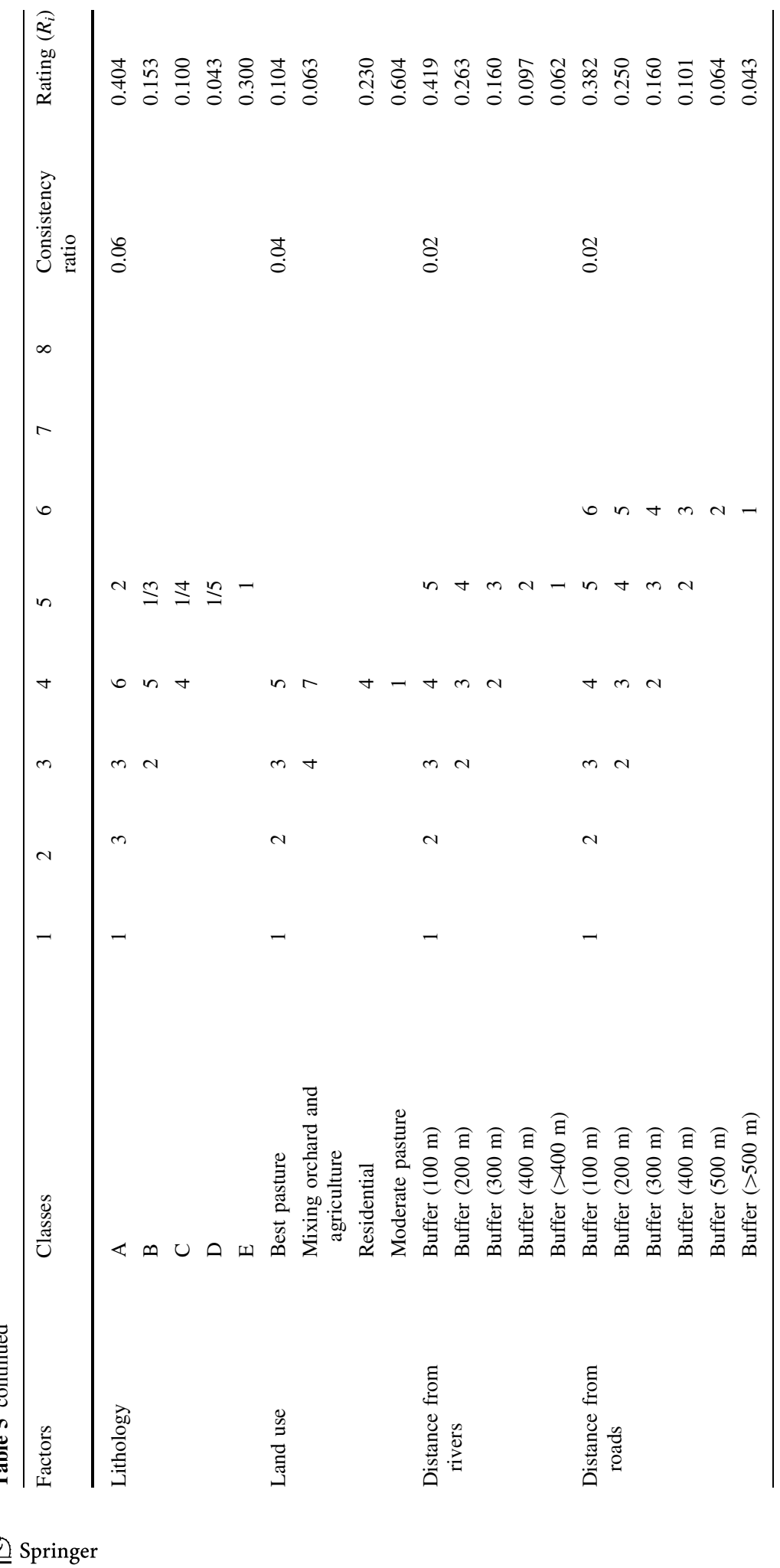




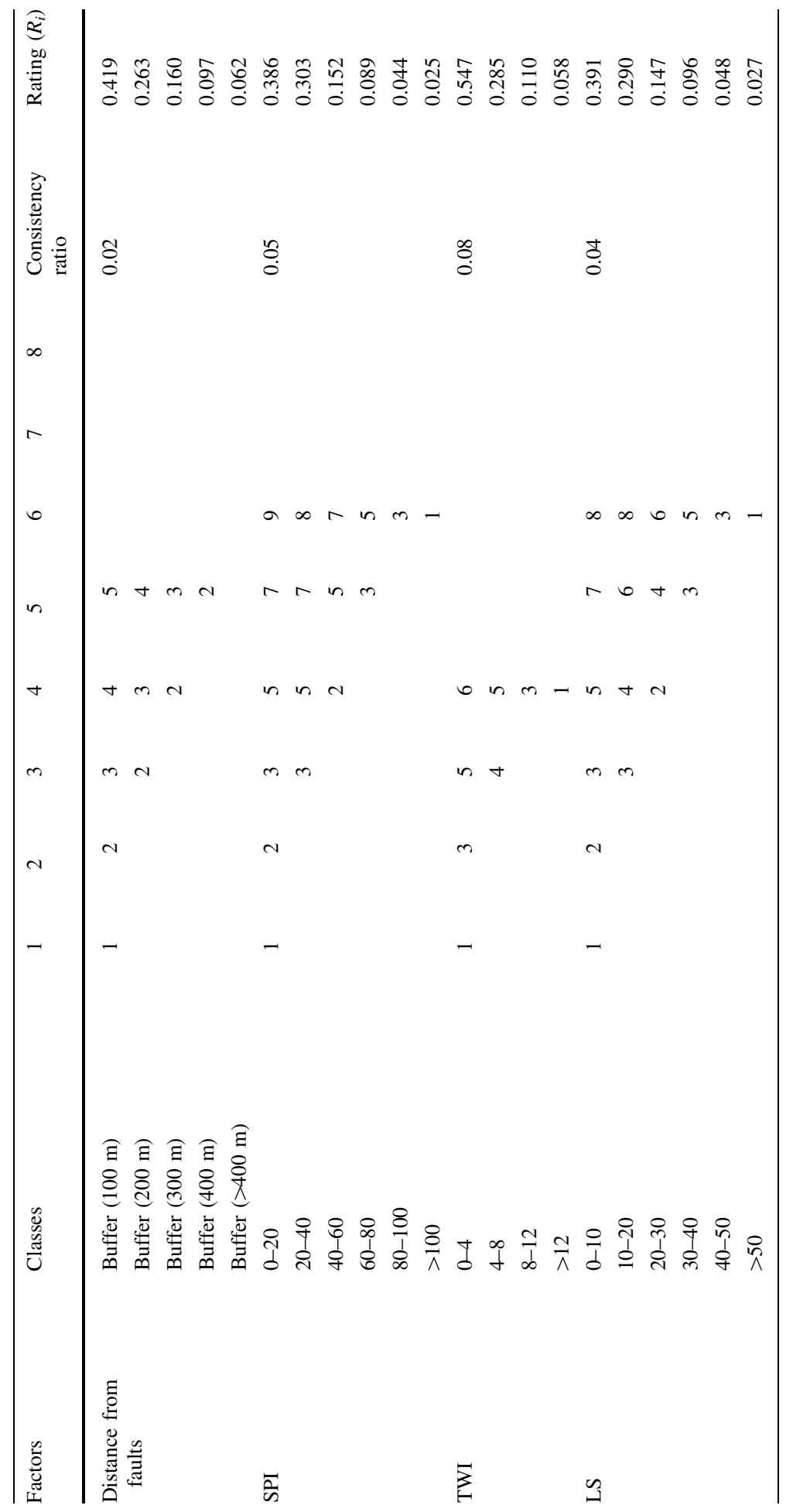




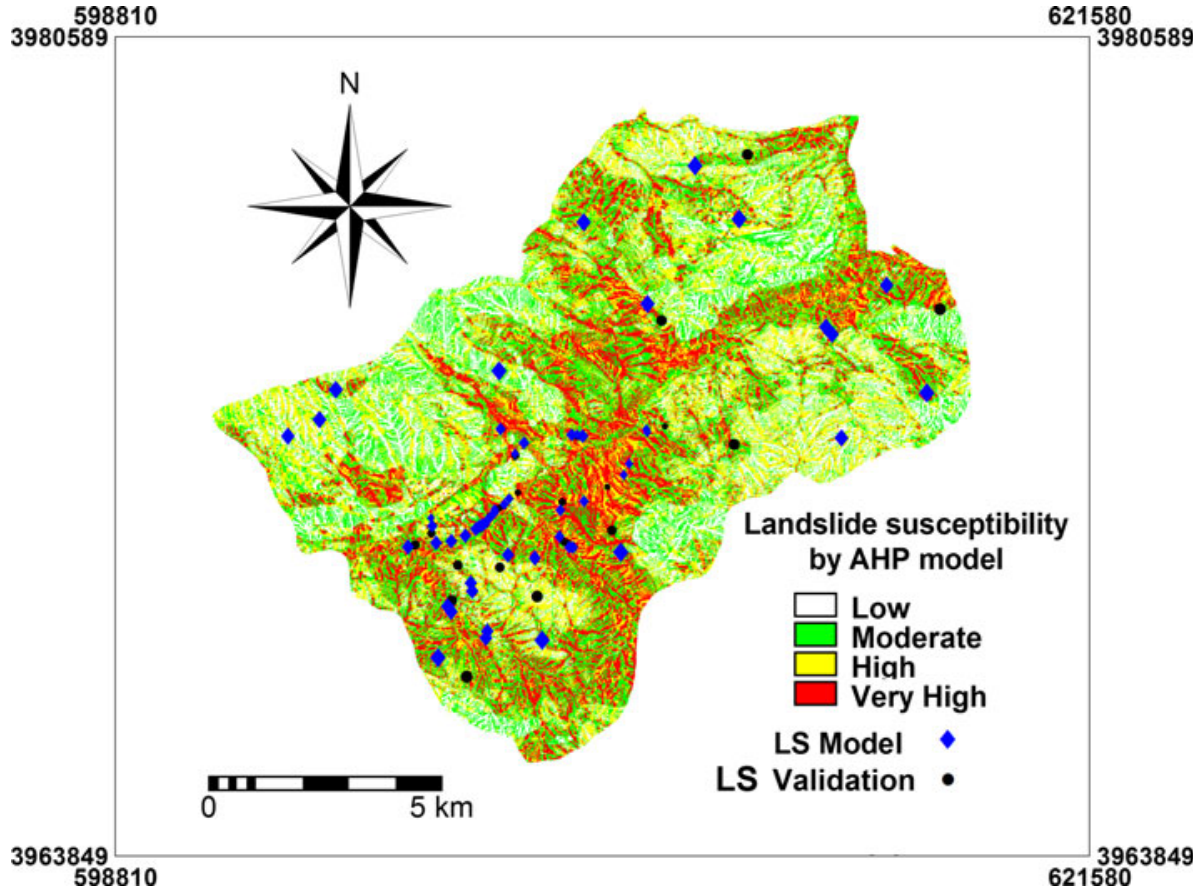

Fig. 4 Landslide susceptibility map based on analytical hierarchy process (AHP) model

For the AHP model, the final result includes the weights of the derived factors, class weights, and a calculated consistency ratio (CR), as seen in Table 6. In the AHP method, an index of inconsistency, known as the consistency ratio (CR), is used to indicate the probability that the matrix judgments were randomly generated (Saaty 1980, 1994).

$$
\mathrm{CR}=(\mathrm{CI} / \mathrm{RI})
$$

where RI is the average of the resulting consistency index depending on the order of the matrix given by Saaty (1980) and CI is the consistency index and can be expressed as:

$$
\mathrm{CI}=\left(\left(\lambda_{\max }-n\right) /(n-1)\right)
$$

where $\lambda_{\max }$ is the largest or principal eigenvalue of the matrix and can be easily calculated from the matrix and $\mathrm{n}$ is the order of the matrix.

The consistency ratio is a ratio between the matrix's consistency index and random index, and in general ranges from 0 to 1 . A CR of 0.1 or less is a reasonable level of consistency (Malczewski 1999). A CR above 0.1 requires revision of the judgment in the matrix due to an inconsistent treatment for particular factor ratings.

With the AHP method, the values of spatial factors weights were defined. Using a weighted linear sum procedure (Voogd 1983), the acquired weights were used to calculate the landslide susceptibility. In this study, the CR is 0.066; the ratio indicates a reasonable level of consistency in the pair-wise comparison that is good enough to recognize the factor weights. Consequently, the weight corresponding to lithology is large, whereas distance from faults is lowest (Table 6). For all cases of the gained class weights, the CRs are less 


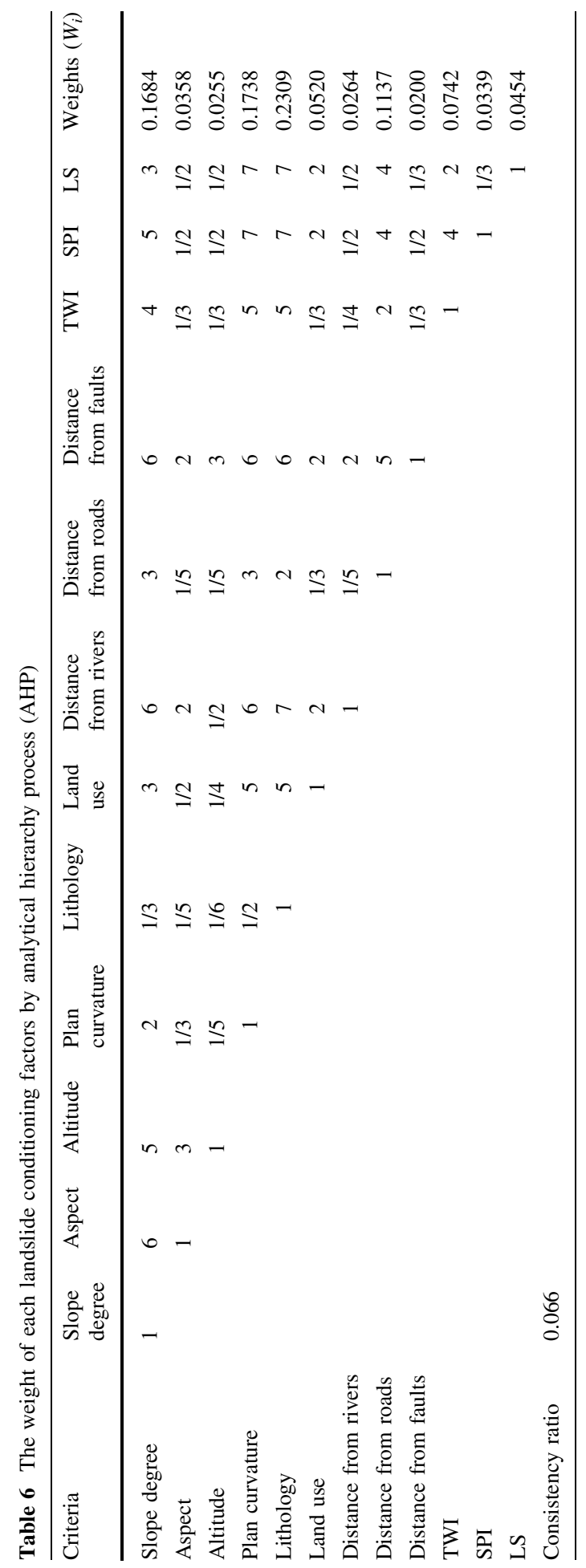


than 0.1 , the ratio indicates a reasonable level of consistency in the pair-wise comparison that was good enough to recognize the class weights. For landslide susceptibility mapping by AHP, we used the following equation;

$$
\mathrm{LSM}=\sum_{i=1}^{n}\left(R_{i} \times W_{i}\right)
$$

where $R_{i}$ is the rating classes each layer and $W_{i}$ is the weights for the each of the landslide conditioning factors.

\section{Validation of the landslide susceptibility maps}

\subsection{Receiver operating characteristics (ROC)}

An important point in prediction models is the task of validating the predicted results that can provides meaningful results. For the purpose of verification, 23 landslide locations (30\%) were used based on the random selection. In this study, the training set is almost twice as big as the testing set. Such a relationship between the model development and testing sets enables representative analytical results (Ayalew et al. 2005). Then, pixel values obtained are classified into low, moderate, high, and very high susceptibility groups to determine the class intervals in the landslide susceptibility maps (Figs. 3, 4). For this purpose, Ayalew et al. (2004) used four types of classifier such as natural breaks, quantiles, equal intervals, and standard deviation to choose the best method. In this case, the natural breaks classifier has been selected as this classification scheme is widely used in the literature. The produced maps were compared with the existing landslide locations. For validation, we used both success rate and prediction rate curve by comparing the existing landslide locations with the two landslide susceptibility maps (Bui et al. 2011). The success rate results were obtained by using the training dataset $70 \%$ (55 landslide locations). Figure 5 shows the success rate curves for fuzzy and AHP models. The model with fuzzy logic has the highest area under the curve (AUC) value (0.9194), whereas AHP has 0.8887. Since the success rate method used the training landslide pixels that have already been used for building the landslide models, the success rate is not a suitable method for assessing the
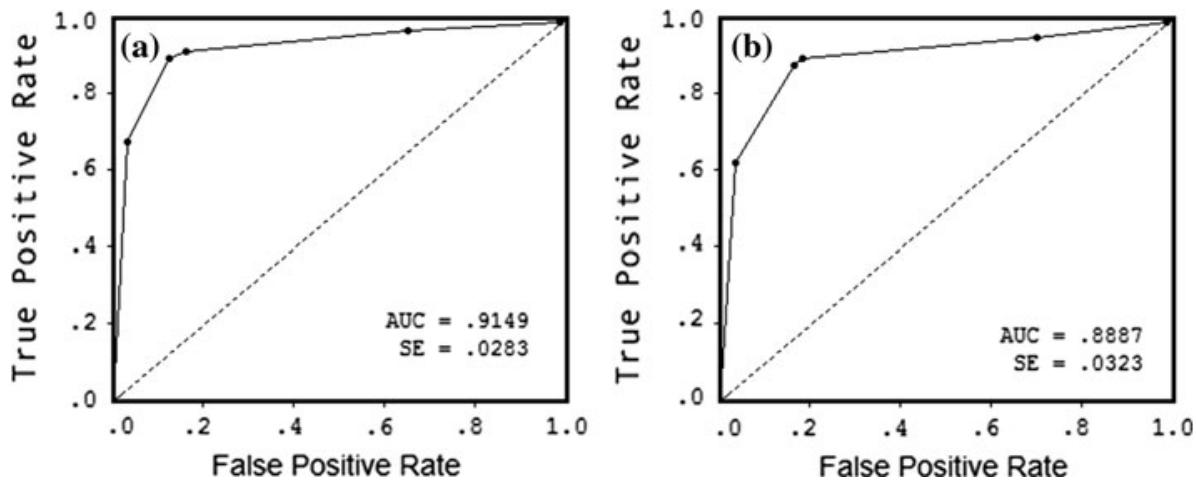

Fig. 5 Success rate curves for the susceptibility maps produced in this study; a fuzzy logic, b AHP 
prediction capability of the models. However, the success rate method may help to determine how well the resulting landslide susceptibility maps have classified the areas of existing landslides (Bui et al. 2011, 2012).

The prediction rate explains how well the model and predictor variable predicts the landslide (Lee 2007; Bui et al. 2011). This method is already widely used as a measure of performance of a predictive rule (Yesilnacar and Topal 2005; Van Den Eeckhaut et al. 2006; Pradhan et al. 2010a; Pourghasemi et al. 2012a, b). The receiver operating characteristics curve (ROC) plots the different accuracy values obtained against the whole range of possible threshold values of the functions, and the ROC serves as a global accuracy statistic for the model, regardless of a specific discriminate threshold. This curve is obtained by plotting all combinations of sensitivities and proportions of false negatives (1-specificity), which may be obtained by varying the decision threshold. The range of values of the ROC curve area is $0.5-1$ for a good fit, while values below 0.5 represent a random fit (Swets 1988). The results of the prediction curve are shown in Fig. 6. From the Fig. 6, it is clear that the susceptibility map using fuzzy logic model, the AUC is 0.8970 , which corresponds to the prediction accuracy of $89.70 \%$, whereas susceptibility map using AHP model, the AUC is 0.8110 and the prediction accuracy is $81.10 \%$ (Fig. 6b).

\subsection{Validation of susceptibility maps by frequency ratio model}

Additionally, to test the reliability of the landslide susceptibility maps produced by the fuzzy logic and AHP methods, frequency ratio was carried out on the classified susceptibility maps and landslide validation data in the first stage. In these comparisons, the distribution of the actual landslide areas is determined according to the landslide susceptibility zones. All of the landslide grid cells were overlaid on four landslide susceptibility zones, and frequency ratio was calculated for each of the susceptibility zones (Pradhan 2010a, b). Theoretically, the frequency ratio value should increase from very low to very high susceptibility zones (Pradhan and Lee 2010b). Figure 7a shows frequency ratio plots of four landslide susceptibility zones for both fuzzy logic and AHP models. Generally, there is a gradual increase in the frequency from the very low susceptible zone to the very high susceptible zone for the study area.
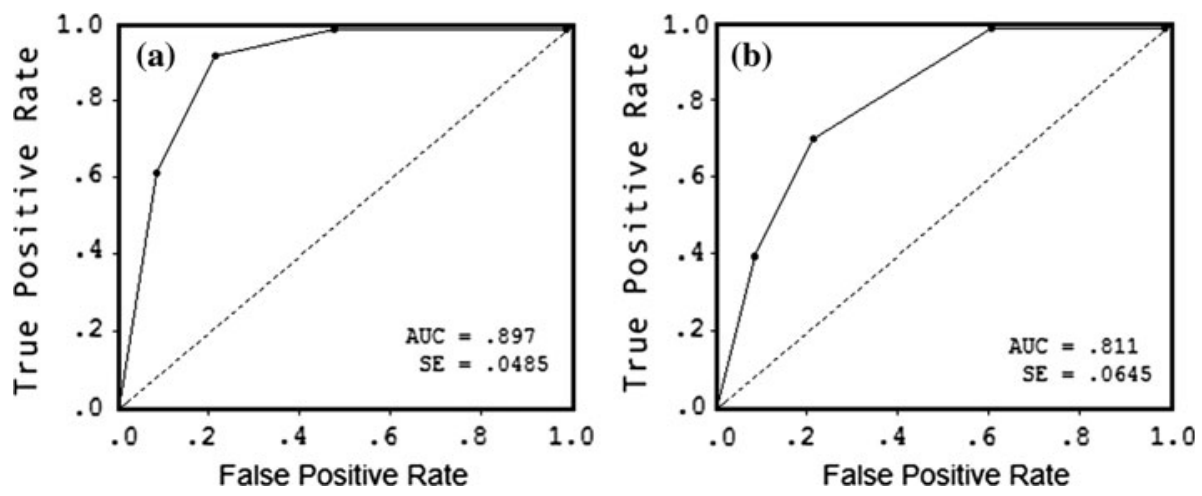

Fig. 6 Prediction rate curves for the susceptibility maps produced in this study; a fuzzy logic, b AHP 


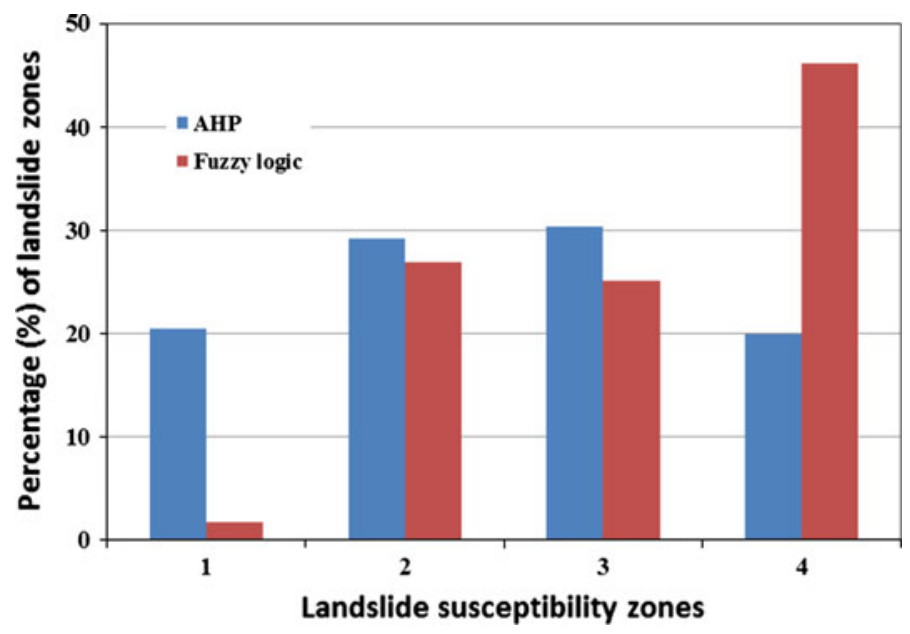

Fig. 7 A histogram showing the percentage of landslide zones that fall into the various classes of the fuzzy logic and AHP susceptibility maps

In the second stage, a separate comparison was made between the two susceptibility maps (produced by fuzzy logic and AHP) according to the landslide susceptibility zones. For evaluation, the two susceptibility maps were first divided into four classes based on natural break of the corresponding histograms (Bui et al. 2011) (Fig. 7b).

\section{Discussions and conclusion}

In this study, both fuzzy logic-based approach and analytical hierarchy process (AHP) have been used for identifying the areas susceptible to landslides in the Haraz Mountains in Iran. A total of 78 landslide locations were mapped using aerial photographs and field surveys. For susceptibility analysis, twelve landslide conditioning factors were used such as slope degree, aspect, altitude, plan curvature, lithology, land use, distance from rivers, distance from roads, distance from faults, SPI, LS, and TWI. A fuzzy logic approach and AHP were applied to analyze the landslide susceptibility using above-mentioned twelve factors. For this purpose, fuzzy membership values are assigned based on frequency ratio model and then normalized. Finally, the fuzzy sets were used to express the input parameters in linguistic forms. The outputs of each parameter have been classified into groups in terms of landslide susceptibility. Considering the fuzzy if-then rules, the fuzzified index maps for each conditioning factors are produced. Grid-based analysis is used to combine the fuzzified index maps and the landslide susceptibility map.

The frequency ratio result (Fig. 7) between the susceptibility zones produced by fuzzy logic and AHP model showed that the high and very high susceptibility zones 3 and 4 contain 19.95, 30.35 (AHP), 46.14, and 25.16\% (fuzzy logic) of the landslide zones, respectively. Approximately 29.18 (AHP) and $26.89 \%$ (fuzzy logic) of the landslide zones coincide with the moderate susceptibility (2) class of two susceptibility maps. In the case of, the low susceptibility class contains approximately 20.52 and $1.8 \%$ of the landslide zones. In Fig. 8, it is indicated that the extent of the landslide zones located in the very high susceptibility class is higher in the map produced by the fuzzy logic than the AHP map. 


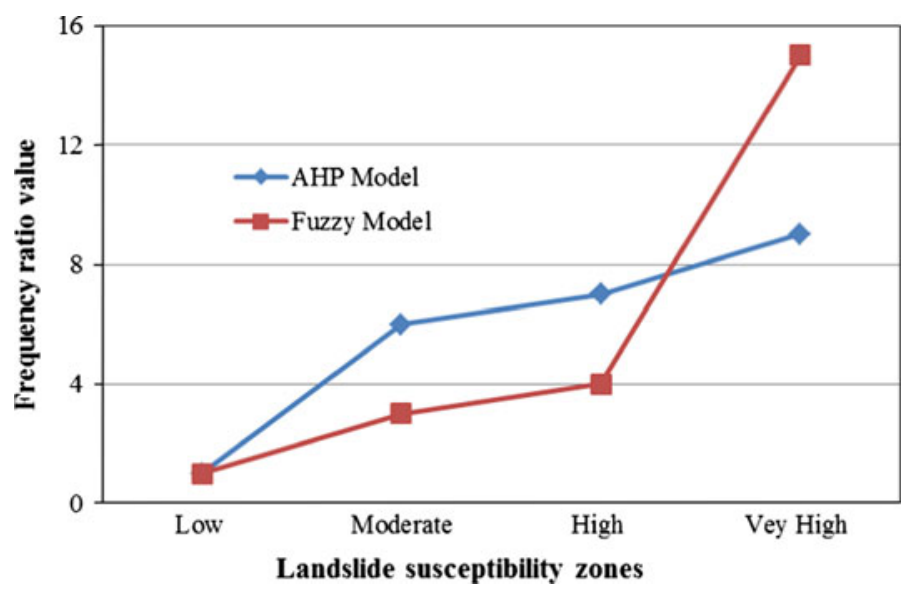

Fig. 8 Frequency ratio plots of four landslide susceptibility zones of the fuzzy logic and AHP models

Whereas in the case of high and moderate zones produced by fuzzy logic, the percentage is slightly decreased as compared to the AHP model. This is also true when the low susceptibility class is considered. Looking at Fig. 8, it is easy to conclude that the very high and high susceptibility classes of the fuzzy logic (71.32 \%) map together captured the locations better than the corresponding counterparts of AHP model (50.3\%). This might be due to the AHP's approach to take the pair-wise comparison as inputs, because the comparison scores are determined on the basis of subjective judgments (Ayalew et al. 2005).

AHP model is conventionally based on a rating system provided by expert opinion. In fact, expert opinion is very useful in solving complex problems like landslides. However, to some extent, opinions may change for every individual expert and thus may be subjected to cognitive limitations with uncertainty and subjectivity. Another aspect is that datadriven methods are also powerful in landslide susceptibility mapping and contain less subjectivity. Therefore, it is important to analyze the spatial relationship between the landslide conditioning factors and landslide locations. The fuzzy logic-based model allows users to order parametric importance before the landslide susceptibility analyses application. It is based on two similarity relation values depicting parametric relationships (by parametric pair wises) on landslide occurrences and landslide locations individually (by each landslide conditioning factor and landslide locations). The first one defines the landslide susceptibility relationships among the parameter pairs, while the second one reflects the relationship between the conditioning factors and landslide locations.

The ROC validation result showed that the fuzzy logic model has better predication accuracy of $8.60 \%(89.70-81.10 \%)$, which is better than the AHP model. Here, the authors can conclude that the results of the fuzzy logic model have shown the best prediction accuracy in landslide susceptibility mapping in the study area. Both ROC curve and frequency ratio validation confirmed that overall fuzzy logic model has higher prediction accuracy than the AHP model. Although the AHP method is fundamentally based on expert opinion, it is thought that the selection of landslide conditioning factors on landslide occurrences alloys the subjectivity concept in this method leading to poor result. Even though models employed in this study produced reasonable result, however, it should be noted that the reliability of the results is directly affected by the landslide location data, that is, the landslide inventory map. 
In summary, the results of this study suggest that landslide susceptibility mapping for the Haraz watershed of Iran is viable. The maps results may be helpful for planners, decision makers, and engineers in slope management and land use planning in the study area. This map is produced in a regional scale, so further study need be carried out at the site-specific level to determine the exact extent site of the slope instability.

Acknowledgments Authors would like to thank two anonymous reviewers for their helpful comments on the previous version of the manuscript.

\section{References}

Akgun A, Turk N (2010) Landslide susceptibility mapping for Ayvalik (Western Turkey) and its vicinity by multi-criteria decision analysis. Environ Earth Sci 61:595-611

Akgun A, Dag S, Fikri B (2008) Landslide susceptibility mapping for a landslide-prone area (Findikli, NE of Turkey) by likelihood-frequency ratio and weighted linear combination models. Environ Geol 54: 1127-1143

Akgun A, Kincal C, Pradhan B (2011) Application of remote sensing data and GIS for landslide risk assessment as an environmental threat to Izmir city (West Turkey). Environ Monit Assess. doi: 10.1007/s10661-011-2352-8

Akgun A, Sezer EA, Nefeslioglu HA, Gokceoglu C, Pradhan B (2012) An easy-to-use MATLAB program (MamLand) for the assessment of landslide susceptibility using a Mamdani fuzzy algorithm. Comput Geosci 38(1):23-34

Aleotti P, Chowdhury R (1999) Landslide hazard assessment: summary review and new perspectives. B Eng Geol Environ 58:21-44

Althuwaynee O, Pradhan B, Lee S (2012) Application of an evidential belief function model in landslide susceptibility mapping. Comput Gesosci (Article online first available). doi:10.1016/j.cageo.2012. 03.003

Alvarez Grima M (2000) Neuro-fuzzy modeling in engineering geology. Balkema, Rotterdam

Ayalew L, Yamagishi H (2005) The application of GIS-based logistic regression for landslide susceptibility mapping in the Kakuda-Yahiko Mountains, Central Japan. Geomorphology 65(1/2):15-31

Ayalew L, Yamagishi H, Ugawa N (2004) Landslide susceptibility mapping using GIS-based weighted linear combination, the case in Tsugawa area of Agano River, Niigata Prefecture, Japan. Landslides 1:73-81

Ayalew L, Yamagishi H, Marui H, Kanno T (2005) Landslides in Sado Island of Japan: Part II. GIS-based susceptibility mapping with comparisons of results from two methods and verifications. Eng Geol 81:432-445

Baeza C, Corominas J (2001) Assessment of shallow landslide susceptibility by means of multivariate statistical techniques. Earth Surf Proc Landf 26:1251-1263

Barredo JI, Benavidesz A, Herh J, Van Westen CJ (2000) Comparing heuristic landslide hazard assessment techniques using GIS in the Tirajana basin, Gran Canaria Island, Spain. Int J Appl Earth Obs 2:9-23

Bednarik M, Magulova B, Matys M, Marschalko M (2010) Landslide susceptibility assessment of the Kralovany-Liptovsky Mikulaš railway case study. Phys Chem Earth 35:162-171

Beven K, Kirkby MJ (1979) A physically based, variable contributing area model of basin hydrology. Hydrol Sci Bull 24:43-69

Biswajeet P, Saied P (2010) Comparison between prediction capabilities of neural network and fuzzy logic techniques for landslide susceptibility mapping. Disaster Adv 3(2):26-34

Bonham-Carter GF (1994) Computer methods in the geosciences, vol 13. Pergamon, Ontario, p 398

Brenning A (2005) Spatial prediction models for landslide hazards: review, comparison and evaluation. Nat Hazard Earth Syst 5(6):853-862

Bui DT, Pradhan B, Lofman O, Revhaug I, Dick OB (2011) Landslide susceptibility mapping at Hoa Binh province (Vietnam) using an adaptive neuro-fuzzy inference system and GIS. Comput Geosci. doi: 10.1016/j.cageo.2011.10.031

Bui DT, Pradhan B, Lofman O, Revhaug I, Dick OB (2012) Spatial prediction of landslide hazards in Hoa Binh province (Vietnam): a comparative assessment of the efficacy of evidential belief functions and fuzzy logic models. Catena 96:28-40. doi:10.1016/j.catena.2012.04.001 
Carrara A, Cardinali M, Guzzetti F, Reichenbach P (1995) GIS technology in mapping landslide hazard. In: Carrara A, Guzzetti F (eds) Geographical information systems in assessing natural hazards. Kluwer, Dordrecht, pp 135-175

Clerici A, Perego S, Tellini C, Vescovi P (2002) A procedure for landslide susceptibility zonation by the conditional analysis method. Geomorphology 48:349-364

Clerici A, Perego S, Tellini C, Vescovi P (2006) A GIS-based automated procedure for landslide susceptibility mapping by the conditional analysis method: The Baganza valley case study (Italian Northern Apennines). Environ Geol 50:941-961

Constantin M, Bednarik M, Jurchescu MC, Vlaicu M (2010) Landslide susceptibility assessment using the bivariate statistical analysis and the index of entropy in the Sibiciu Basin (Romania). Environ Earth Sci. doi:10.1007/s12665-010-0724-y

Dai FC, Lee CF, Xu ZW (2001) Assessment of landslide susceptibility on the natural terrain of Lantau Island, Hong Kong. Environ Geol 40(3):381-391

Duman TY, Can T, Gokceoglu C, Nefeslioglu HA, Sonmez H (2006) Application of logistic regression for landslide susceptibility zoning of Cekmece Area, Istanbul, Turkey. Environ Geol 51:241-256

Eastman RJ (2003) IDRISI Kilimanjaro guide to GIS and image processing, manual version 14.00, pp 328

Ercanoglu M, Gokceoglu C (2002) Assessment of landslide susceptibility for a landslide-prone area (North of Yenice, NW Turkey) by fuzzy approach. Environ Geol 41:720-730

Ercanoglu M, Gokceoglu C (2004) Use of fuzzy relations to produce landslide susceptibility map of a landslide prone area (West Black Sea Region, Turkey). Eng Geol 75:229-250

Ercanoglu M, Gokceoglu C, Van Asch WJ (2004) Landslide susceptibility zoning of North of Yenice (NW Turkey) by multivariate statistical techniques. Nat Hazards 32:1-23

Ercanoglu M, Kasmer O, Temiz N (2008) Adaptation and comparison of expert opinion to analytical hierarchy process for landslide susceptibility mapping. Bull Eng Geol Environ 67:565-578

Erner A, Sebnem H, Duzgun B (2010) Improvement of statistical landslide susceptibility mapping by using spatial and global regression methods in the case of More and Romsdal (Norway). Landslides 7:55-68

Falaschi F, Giacomelli F, Federici PR, Puccinelli A, D’Amato Avanzi G, Pochini A, Ribolini A (2009) Logistic regression versus artificial neural networks: landslide susceptibility evaluation in a sample area of the Serchio River valley, Italy. Nat Hazards 50:551-569

Fernandez CI, Del Castillo TF, El Hamdouni R, Montero JC (1999) Verification of landslide susceptibility mapping: a case study. Earth Surf Proc Landf 24:537-544

Foumelis M, Lekkas E, Parcharidis I (2004) Landslide susceptibility mapping by GIS-based qualitative weighting procedure in Corinth area. Bulletin of the Geological Society of Greece XXXVI, 904-912. Proceedings of the 10th international congress, Thessaloniki, April 2004

Gokceoglu C, Aksoy H (1996) Landslide susceptibility mapping of the slopes in the residual soils of the Mengen region (Turkey) by deterministic stability analyses and image processing techniques. Eng Geol 44:147-161

Guzzetti F, Carrarra A, Cardinali M, Reichenbach P (1999) Landslide hazard evaluation: a review of current techniques and their application in a multi-scale study, Central Italy. Geomorphology 31:81-216

Hines JW (1997) Fuzzy and neural approaches in engineering. Wiley, New York, NY

Hutchinson JN (1995) Landslide hazard assessment. In: Proceedings of the 6th international symposium on landslide, Christchurch, 1, New Zealand, pp 1805-1842

Iranian Landslide Working Party (ILWP) (2007) Iranian landslides list, forest. Rangeland and Watershed Association, Iran, p 60

Juang CH, Lee DH, Sheu C (1992) Mapping slope failure potential using fuzzy sets. J Geotech Eng Div ASCE 118:475-493

Kanungo DP, Arora MK, Gupta RP, Sarkar S (2005) GIS based landslide hazard zonation using neuro-fuzzy weighting. In: Proceedings of the 2nd industrial international conference on artificial intelligence (IICAI-05), Pune, pp 1222-1237

Komac M (2006) A landslide susceptibility model using the analytical hierarchy process method and multivariate statistics in perialpine Slovenia. Geomorphology 74:17-28

Lee S (2005) Application of logistic regression model and its validation for landslide susceptibility mapping using GIS and remote sensing data. Int J Remote Sens 26:1477-1491

Lee S (2007) Application and verification of fuzzy algebraic operators to landslide susceptibility mapping. Environ Geol 50:847-855

Lee S, Min K (2001) Statistical analysis of landslide susceptibility at Yongin, Korea. Environ Geol 40:1095-1113

Lee S, Pradhan B (2006) Probabilistic landslide risk mapping at Penang Island, Malaysia. J Earth Syst Sci 115(6):661-672 
Lee S, Pradhan B (2007) Landslide hazard mapping at Selangor, Malaysia using frequency ratio and logistic regression models. Landslides 4:33-41

Lee S, Sambath T (2006) Landslide susceptibility mapping in the Damrei Romel area, Cambodia using frequency ratio and logistic regression models. Environ Geol 50:847-855

Lee S, Choi J, Min K (2004a) Probabilistic landslide hazard mapping using GIS and remote sensing data at Boun, Korea. Int J Remote Sens 25:2037-2052

Lee S, Ryu JH, Won JS, Park H (2004b) Determination and application of the weights for landslide susceptibility mapping using an artificial neural network. Eng Geol 71:289-302

Lee S, Choi J, Oh H (2009) Landslide susceptibility mapping using a neuro-fuzzy. Abstract presented at American Geophysical Union, Fall Meeting 2009, abstract \#NH53A-1075

Malczewski J (1999) GIS and multi-criteria decision analysis. Wiley, New York, p 392

Moore ID, Burch GJ (1986) Sediment transport capacity of sheet and rill flow: application of unit stream power theory. Water Res 22:1350-1360

Moore ID, Grayson RB, Ladson AR (1991) Digital terrain modeling: a review of hydrological, geomorphological, and biological applications. Hydrol Process 5:3-30

Moore ID, Wilson JP (1992) Length-slope factors for the revised universal soil loss equation: simplified method of estimation. J Soil Water Conserv 47:423-428

Mowen X, Esaki T, Zhou G, Mitani Y (2003) Geographic information systems-based three-dimensional critical slope stability analysis and landslide hazard assessment. J Geotech Geoenviron 129:1109-1119

Nefeslioglu HA, Sezer E, Gokceoglu C, Bozkir AS, Duman TY (2010) Assessment of landslide susceptibility by decision trees in the Metropolitan area of Istanbul, Turkey. Math Probl Eng. doi: $10.1155 / 2010 / 901095$

Nefeslioğlu HA, Gokceoglu C, Sonmez H (2008a) An assessment on the use of logistic regression and artificial neural networks with different sampling strategies for the preparation of landslide susceptibility maps. Eng Geol 97(3/4):171-191

Nefeslioğlu HA, Duman TY, Durmaz S (2008b) Landslide susceptibility mapping for a part of tectonic Kelkit Valley (Eastern Black Sea region of turkey). Geomorphology 94(3-4):401-418

Nie HF, Diao SJ, Liu JX, Huang H (2001) The application of remote sensing technique and AHP-fuzzy method in comprehensive analysis and assessment for regional stability of Chongqing City, China. In Proceedings of the 22nd international Asian conference on remote sensing, vol 1, pp 660-665

Ocakoglu F, Gokceoglu C, Ercanoglu M (2002) Dynamics of a complex mass movement triggered by heavy rainfall: a case study from NW Turkey. Geomorphology 42(3):329-341

Oh HJ, Pradhan B (2011) Application of a neuro-fuzzy model to landslide susceptibility mapping for shallow landslides in tropical hilly area. Comput Geosci 37(9):1264-1276

Pachauri AK, Gupta PV, Chander R (1998) Landslide zoning in a part of the Garhwal Himalayas. Environ Geol 36(3-4):325-334

Park NW (2010) Application of Dempster-Shafer theory of evidence to GIS-based landslide susceptibility analysis, Environ Earth Sci. doi:10.1007/s12665-010-0531-5

Pourghasemi HR (2008) Landslide hazard assessment using fuzzy logic (case study: a part of Haraz watershed), a thesis presented for M.Sc. degree in watershed management, Faculty of Natural Resources, Department of Watershed Management, Tarbiat Modarres University, Iran, 92 pp

Pourghasemi HR, Pradhan B, Gokceoglu C, Mohammadi M Moradi HR (2012a) Application of weights-ofevidence and certainty factor models and their comparison in landslide susceptibility mapping at Haraz watershed, Iran. Arab J Geosci. doi:10.1007/s12517-012-0532-7

Pourghasemi HR, Pradhan B, Gokceoglu C, Moezzi KD (2012b) A comparative assessment of prediction capabilities of Dempster-Shaferand weights-of-evidence models in landslide susceptibility mapping using GIS. Geomat Nat Hazards Risk. doi:10.1080/19475705.2012.662915

Pouydal CP, Chang C, Oh HJ, Lee S (2010) Landslide susceptibility maps comparing frequency ratio and artificial neural networks: a case study from the Nepal Himalaya. Environ Earth Sci 61:1049-1064

Pradhan B (2010a) Remote sensing and GIS-based landslide hazard analysis and cross-validation using multivariate logistic regression model on three test areas in Malaysia. Adv Space Res 45:1244-1256

Pradhan B (2010b) Use of GIS-based fuzzy logic relations and its cross application to produce landslide susceptibility maps in three test areas in Malaysia. Environ Earth Sci. doi:10.1007/s12665-010-0705-1

Pradhan B (2010c) Landslide susceptibility mapping of a catchment area using frequency ratio, fuzzy logic and multivariate logistic regression approaches. J Indian Soc Remote Sens 38(2):301-320. doi: 10.1007/s12524-010-0020-z

Pradhan B (2011a) Manifestation of an advanced fuzzy logic model coupled with geoinformation techniques for landslide susceptibility analysis. Environ Ecol Stat 18(3):471-493. doi:10.1007/s10651-010-0147-7

Pradhan B (2011b) Use of GIS-based fuzzy logic relations and its cross application to produce landslide susceptibility maps in three test areas in Malaysia. Environ Earth Sci 63(2):329-349 
Pradhan B, Buchroithner MF (2010) Comparison and validation of landslide susceptibility maps using an artificial neural network model for three test areas in Malaysia. Environ Eng Geosci 16(2):107-126. doi:10.2113/gseegeosci.16.2.107

Pradhan B, Lee S (2007) Utilization of optical remote sensing data and GIS tools for regional landslide hazard analysis by using an artificial neural network model. Earth Sci Front 14(6):143-152

Pradhan B, Lee S (2009) Landslide risk analysis using artificial neural network model focusing on different training sites. Int J Phys Sci 3(11):1-15

Pradhan B, Lee S (2010a) Delineation of landslide hazard areas on Penang Island, Malaysia, by using frequency ratio, logistic regression, and artificial neural network models. Environ Earth Sci 60:1037-1054

Pradhan B, Lee S (2010b) Landslide susceptibility assessment and factor effect analysis: back-propagation artificial neural networks and their comparison with frequency ratio and bivariate logistic regression modeling. Environ Modell Softw 25(6):747-759

Pradhan B, Lee S (2010c) Remote sensing and GIS-based landslide susceptibility analysis and its crossvalidation in three test areas using a frequency ratio model. Photogramm Fernerkun 1:17-32. doi: $10.1127 / 14328364 / 2010 / 0037$

Pradhan B, Youssef AM (2010) Manifestation of remote sensing data and GIS on landslide hazard analysis using spatial-based statistical models. Arab J Geosci 3(3):319-326

Pradhan B, Singh RP, Buchroithner MF (2006) Estimation of stress and its use in evaluation of landslide prone regions using remote sensing data. Adv Space Res 37:698-709

Pradhan B, Lee S, Mansor S, Buchroithner MF, Jallaluddin N, Khujaimah Z (2008) Utilization of optical remote sensing data and geographic information system tools for regional landslide hazard analysis by using binomial logistic regression model. J Appl Remote Sens 2:1-11

Pradhan B, Lee S, Buchroithner MF (2009) Use of geospatial data for the development of fuzzy algebraic operators to landslide hazard mapping: a case study in Malaysia. Appl Geomatics 1:3-15

Pradhan B, Lee S, Buchroithner MF (2010a) A GIS-based back-propagation neural network model and its cross-application and validation for landslide susceptibility analyses. Comput Environ Urban 34(3):216235

Pradhan B, Oh HJ, Buchroithner M (2010b) Weights-of-evidence model applied to landslide susceptibility mapping in a tropical hilly area. Geomatics Nat Hazards Risk 1(3):199-223. doi:10.1080/19475705. 2010.498151

Pradhan B, Sezer EA, Gokceoglu C, Buchroithner MF (2010c) Landslide susceptibility mapping by neurofuzzy approach in a landslide prone area (Cameron Highland, Malaysia). IEEE Trans Geosci Remote Sens 48(12):4164-4177

Pradhan B, Youssef AM, Varathrajoo R (2010d) Approaches for delineating landslide hazard areas using different training sites in an advanced artificial neural network model. Geo-Spat Inform Sci 13(2):93-102. doi:10.1007/s11806-010-0236-7

Pradhan B, Mansor S, Pirasteh S, Buchroithner M (2011) Landslide hazard and risk analyses at a landslide prone catchment area using statistical based geospatial model. Int J Remote Sens 32(14):4075-4087. doi:10.1080/01431161.2010.484433

Ram Mohan V, Jeyaseelan A, Naveen Raj T, Narmatha T, Jayaprakash M (2011) Landslide susceptibility mapping using frequency ratio method and GIS in south eastern part of Nilgiri District, Tamilnadu, India. Int J Geomatics Geosci 1(4):951-961

Saaty TL (1977) A scaling method for priorities in hierarchical structures. J Math Psychol 15:234-281

Saaty TL (1980) The analytical hierarchy process. McGraw-Hill, New York

Saaty TL (1994) Fundamentals of decision making and priority theory with analytic hierarchy process. RWS Publications, Pittsburgh

Saaty TL (2000) Decision making for leaders: the analytical hierarchy process for decisions in a complex world. RWS Publications, Pittsburgh

Saaty TL, Vargas LG (2001) Models, methods, concepts and applications of the analytic hierarchy process. Kluwer, Dordrecht

Saha AK, Gupta RP, Arora MK (2002) GIS-based landslide hazard zonation in the Bhagirathi (Ganga) valley, Himalayas. Int J Remote Sens 23(2):357-369

Saha AK, Gupta RP, Sarkar I, Arora MK, Csaplovics E (2005) An approach for GIS-based statistical landslide susceptibility zonation with a case study in the Himalayas. Landslides 2:61-69

Sezer EA, Pradhan B, Gokceoglu C (2011) Manifestation of an adaptive neuro-fuzzy model on landslide susceptibility mapping: Klang valley, Malaysia. Expert Syst Appl 38(7):8208-8219

Swets JA (1988) Measuring the accuracy of diagnostic systems. Science 240:1285-1293 
Tunusluoglu MC, Gokceoglu C, Nefeslioglu HA, Sonmez H (2008) Extraction of potential debris source areas by logistic regression technique: a case study from Barla, Besparmak and Kapi mountains (NW Taurids, Turkey). Environ Geol 54:9-22

Vahidnia MH, Alesheikh AA, Alimohammadi A, Hosseinali F (2010) A GIS-based neurofuzzy procedure for integrating knowledge and data in landslide susceptibility mapping. Comput Geosci 36:1101-1114

Van Den Eeckhaut M, Vanwalleghem T, Poesen J, Govers G, Verstraeten G, Vandekerckhove L (2006) Prediction of landslide susceptibility using rare events logistic regression: a case-study in the Flemish Ardennes (Belgium). Geomorphology 76:392-410

Van Westen CJ, Bonilla JBA (1990) Mountain hazard analysis using PC-based GIS. 6th IAEG congress, vol 1. Balkema, Rotterdam, pp 265-271

Van Westen CJ, Seijmonsbergen AC, Mantovani F (1999) Comparing landslide hazard maps. Nat Hazards 20:137-158

Varnes DJ (1978) Slope movement types and processes. In: Schuster RL, Krizek RJ (eds) Landslides analysis and control. Special report, vol 176. Transportation Research Board, National Academy of Sciences, New York, pp 11-33

Varnes DJ (1981) Slope stability problems of the circum Pacific region as related to mineral and energy resource. In: Halbouty MT (ed) Energy resources of the Pacific region. American Association of Petroleum Geologists Studies in Geology. No. 12, American Association of Petroleum Geologist, Tulsa, Okla., pp 489-505

Voogd H (1983) Multi-criteria evaluation for urban and regional planning. Pion Ltd, London

Wang HB, Sassa K (2005) Comparative evaluation of landslide susceptibility in Minamata area, Japan. Environ Geol 47:956-966

Wilson JP, Gallant JC (2000) Terrain analysis principles and applications. Wiley, New York, NY, USA

Xu C, Xu X, Dai F, Xiao J (2012) Landslide hazard mapping using GIS and weight of evidence model in Qingshui River watershed of 2008 Wenchuan earthquake struck region. J Earth Sci 23(1):97-120

Yagi H (2003) Development of assessment method for landslide hazardness by AHP. Abstract volume of the 42nd annual meeting of the Japan Landslide Society, pp 209-212

Yalcin A (2008) GIS-based landslide susceptibility mapping using analytical hierarchy process and bivariate statistics in Ardesen (Turkey): comparisons of results and confirmations. Catena 72:1-12

Yalcin A, Bulut F (2007) Landslide susceptibility mapping using GIS and digital photogrammetric techniques: a case study from Ardesen (NE-Turkey). Nat Hazards 41:201-226

Yao X, Tham LG, Dai FC (2008) Landslide susceptibility mapping based on support vector machine: a case study on natural slopes of Hong Kong, China. Geomorphology 101:572-582

Yesilnacar E, Topal T (2005) Landslide susceptibility mapping: a comparison of logistic regression and neural networks methods in a medium scale study, Hendek region (Turkey). Eng Geol 79(3-4):251266

Yilmaz I (2010) Comparison of landslide susceptibility mapping methodologies for Koyulhisar, Turkey: conditional probability, logistic regression, artificial neural networks, and support vector machine. Environ Earth Sci 61(4):821-836

Yoshimatsu H, Abe S (2006) A review of landslide hazards in Japan and assessment of their susceptibility using an analytical hierarchic process (AHP) method. Landslides 3:149-158

Youssef AM, Pradhan B, Gaber AFD, Buchroithner MF (2009) Geomorphological hazard analysis along the Egyptian Red Sea coast between Safaga and Quseir. Nat Hazard Earth Sys 9:751-766. doi: 10.5194/nhess-9-751-2009

Youssef AM, Pradhan B, Sabtan AA, El-Harbi HM (2012) Coupling of remote sensing data aided with field investigations for geological hazards assessment in Jazan area, Kingdom of Saudi Arabia. Environ Earth Sci 65(1):119-130. doi:10.1007/s12665-011-1071-3

Zadeh LA (1965) Fuzzy sets. Inf Control 8:338-352

Zadeh LA (1973) Outline f a new approach to the analysis of complex systems and decision processes. IEEE Trans Syst Man Cybern SMC-3 1:28-46 